\title{
Spatial sedimentary distribution, seasonality and the characteristics of organic matter on Fernando de Noronha insular shelf
}

\author{
Roberto Lima Barcellos ${ }^{1 *}$, Liza Ellen Eurico de Oliveira ${ }^{1}$, Manuel de Jesus Flores-Montes ${ }^{l}$ \\ ${ }^{1}$ Laboratório de Oceanografia Geológica da Universidade Federal de Pernambuco \\ (Avenida da Arquitetura s/n, Cidade Universitária - Recife - PE - 50.740-550, Brazil) \\ *Corresponding author: roberto.barcellos@ufpe.br
}

\section{Abstract}

The present study was conducted in the Fernando de Noronha archipelago $\left(4^{\circ} \mathrm{S} / 32^{\circ} \mathrm{W}\right)$. The objective is the evaluation of the spatial distribution and seasonal variations in the sediments and sedimentary organic matter in the northern insular shelf of Fernando de Noronha ("Mar de Dentro"). Nineteen surface sediment samples were collected between December 2013, July 2014 and November 2014. The studied methods included analysis of the grain size, coarse fraction, morphoscopy, total organic matter content, calcium carbonate, organic carbon, total nitrogen, sedimentary phosphorus (organic, inorganic and total), elemental ratios $(\mathrm{C} / \mathrm{N}, \mathrm{C} / \mathrm{P})$ and stable isotopic ratios $(\delta 13 \mathrm{C}-\delta 15 \mathrm{~N})$. The results allowed to infer that there is no seasonal variation in sediment distribution. Whereas, the shelf sediments present a calcareous sandy sedimentary cover $(\mathrm{CaCO} 3 \approx$ $88.3 \%$ ), predominantly of well-sorted fine sands, with low organic matter content $(\mathrm{TOM}<2.87 \%$, $\mathrm{TOC}<4.29 \%, \mathrm{TP}<0.44 \mu \mathrm{mol} / \mathrm{g}$ ) and are mainly of marine origin $\left(\delta^{13} \mathrm{C} \approx-22.17 \% \mathrm{PDB}\right)$. As conclusions was observed a spatial variation, where the southwestern part is dominated by gravelly and northeast part is composed for fine sand, conditioned by the bottom morphology, sediments sources and, wave action. The geochemistry showed some stations with relative enrichment in organic matter content (TOC $>3.0 \% ; \mathrm{TN}>0.4 \%$ ) of mixed origin $\left(\delta^{13} \mathrm{C}=-24.5\right.$ to $\left.-23.0 \% \mathrm{PDB}\right)$, which were related to anthropogenic impacts and the biotic and abiotic local processes.

Descriptors: Marine sediments, Insular shelf, Bioclasts, Sedimentary organic matter, $\delta^{13} \mathrm{C}$ ratio, South Atlantic.

\section{RESUMO}

$\mathrm{O}$ presente estudo, realizado no arquipélago de Fernando de Noronha $\left(4^{\circ} \mathrm{S} / 32^{\circ} \mathrm{W}\right)$, teve como objetivo a avaliação da distribuição espacial e variações sazonais dos sedimentos e matéria orgânica sedimentar da plataforma insular norte de Fernando de Noronha ("Mar de Dentro"). Ao todo, 19 amostras de sedimentos foram coletadas entre dezembro de 2013, julho de 2014 e novembro de 2014. Os métodos analisados foram a granulometria, análise da fração arenosa, morfoscopia, teores de matéria orgânica total, carbonato de cálcio, carbono orgânico, nitrogênio total, fósforo sedimentar (orgânico, inorgânico e total), razões elementares $(\mathrm{C} / \mathrm{N}$ e $\mathrm{C} / \mathrm{P})$ e razões isotópicas estáveis $(\delta 13 \mathrm{C}$ e $\delta 15 \mathrm{~N})$. Os resultados obtidos permitiram inferir que não há variação sazonal na distribuição sedimentar. Visto que os sedimentos da plataforma apresentam uma cobertura sedimentar carbonática $(\mathrm{CaCO} 3 \approx 88,3 \%)$, predominantemente de areias finas bem selecionadas, com baixos conteúdos orgânicos (MOT $<2,87 \%$, COT $<4,29 \%$, PT $<0,44 \mu \mathrm{mol} / \mathrm{g}$ ) de origem marinha $\left(\delta^{13} \mathrm{C} \approx-22,17 \% \mathrm{PDB}\right)$ em todos os períodos. Como conclusão, observou-se que ocorre uma mudança espacial, onde a parte SW é mais cascalhosa e a porção NE composta por areia fina, condicionada pela morfologia de fundo, fontes de sedimentos e ação das ondas. A geoquímica evidenciou algumas estações mais enriquecidas, com matéria orgânica (COT $>3,0 \%$; NT $>0,4 \%)$ de origem mista $\left(\delta^{13} \mathrm{C}=-24,5\right.$ a $\left.-23,0 \% \mathrm{PDB}\right)$, que foram associadas aos inputs antrópicos e aos processos bióticos e abióticos locais.

Descritores: Sedimentos marinhos, Plataforma insular, Bioclastos, Matéria orgânica sedimentar, Razão $\delta^{13} \mathrm{C}$, Atlântico Sul. 


\section{INTRODUCTION}

The modern sedimentary cover present on continental shelves is the result of its predominant character (terrigenous or carbonate), its origin (autochthonous or allochthonous) and the transport and reworking occasioned by the local and adjacent hydrodynamic activity such as that of waves, tides and currents (Ponzi, 2004). According to Johnson and Baldwin (1996), terrigenous components, classified as allochthonous, are introduced onto the shelf mainly by the rivers. There are, further, the terrigenous relict sediments derived from the reworking of old deposits related to the transgression cycles and marine regression, known as palimpsests (McManus, 1975). In the case of the autochthonous particles in shelf sediments, they are mainly derived from the erosion of the biogenic material formed by the accumulation of layers of the carbonate shells that generally occur in shallow water bodies. These deposits are conditioned by the primary productivity and variety that are correlated with climatic conditions, temperature, salinity, photic intensity, and with secondary activities such as turbidity, substrate sources, nutrient flow and hydrodynamic regime, that permit the classification of these components as native (Wilson, 2012; Ponzi, 2004; Johnson and Baldwin, 1996).

The sediment, either of autochthonous or allochthonous origin, is composed of particles of both inorganic and organic materials which accumulate in unbound mode, preserving the historical record of the environment, through their texture, maturity and composition (Ponzi, 2004; Thurman, 1994; Garrison, 2016). One of the sedimentary components is the organic matter employed as a tracer in sedimentary studies, focusing on the interaction between the atmosphere, biosphere and geosphere. Thus the characterization of this sediment component shows its contribution to marine cycles - their origin, nature and destiny - as well as the comprehension of the global carbon cycle (Tyson, 1995; Meyers, 1997; Dias and Lima, 2004).

Oceanic island shelves occupy only a small portion of the total surface of the Earth and are very particular sedimentary environments. However, their frequent occurrence and use along the majority of the tropical and temperate coasts of the world must be born in mind, in the light of their substantial environmental and socio-economic importance (Stronge, 1994). On the other hand, oceanic island systems are fragile and require specific planning measures for the management of their ecosystems as they are highly sensitive environments from a geoecosystem point of view (Clark, 1977).
In recent decades an increase has been observed in the number of studies conducted on calcareous beach systems on oceanic islands, such as those by Kench (1997), Norcross et al. (2002), Smith and Cheung (2002), Eversole and Fletcher (2003), Genz et al. (2007), Pessenda et al. (2008), Pereira et al. (2010); Manso et al. (2011), and Barcellos et al. (2011, 2016a). However, studies on sedimentology, with a multi-proxy approach, on oceanic island shelves are still few. Specially focusing on the sedimentary organic matter behavior that is very particular in this type of marine environment. Oceanic island shelves are very dynamic in hydrodynamic point of view and are subject to a limited organic matter $(\mathrm{OM})$ terrigenous inputs, leading to a biogenic sediment character, dominated in general by $\mathrm{OM}$ of marine origin in tropical areas (Montalvo et al., 2010; Yamamuro and Kamiya, 2014; Reidhaar et al., 2016; Ennis et al., 2016).

The OM is often employed as dynamic indicator in the marine environment due to its character of being absorbed by clay minerals 4 and 2 times more than sands and silts, respectively (Pettijohn, 1975). Thus, high OM contents are related to high silt/clay contents directly correlated to low hydrodynamic areas, or also to a high primary productivity in subjacent water column (Tyson, 1995). Besides these factors, $\mathrm{OM}$ is also a good tool for environmental evaluation, so it is employed in the correlation of various oceanographic processes such as land-derived material inputs, water masses dynamics, oxi-reduction potential, sedimentation rates, sedimentary processes associated to a local hydrodynamics and indicator of sources and tracer flows in depositional sites (Romankevich, 1984; Thornton and McManus, 1994; Meyers, 1997; Ogrinc et al., 2005; Lamb et al., 2006).

This article thus presents novel data, representing a pioneer study of shelf sedimentation and geochemistry on the Fernando de Noronha archipelago, western South Atlantic (NE, Brazil). This research then sought to study the seasonal and spatial sedimentary processes and the geochemistry of the FN archipelago's north insular shelf, with special focus on its sedimentary organic matter characteristics as environmental and hydrodynamic indicator.

\section{MATERIAL AND METHODS}

\section{STUDY SITE}

The Fernando de Noronha archipelago is located on the central coordinates $3^{\circ} 52^{\prime} \mathrm{S}$ and $32^{\circ} 26^{\prime} \mathrm{W}$. Belonging to the state of Pernambuco (NE Brazil), it is located about 
$545 \mathrm{~km}$ from Recife, has a total area of $26 \mathrm{Km}^{2}$ and an altitude ranging from 0 to $321 \mathrm{~m}$ - the highest peak (Figure 1). The archipelago consists of the main island of the same name and another 21 smaller islands and islets of volcanic origin. It had a population of 2,629 at the last census, in 2010 (IBGE, 2010). Human occupation is restricted to $35 \%$ of the main island, whose activities are mainly related to tourism (Mendes, 2006).

The archipelago is the top of a volcanic cone of a seamount whose base (with a diameter of $74 \mathrm{~km}$ ) is located on the ocean floor at a depth of about $4,200 \mathrm{~m}$ and whose origin is associated with an intra-plate hot-spot process. The profile of the extinct volcanic construction also has a secondary elevation, the Alto Drina, which is located 23 $\mathrm{km}$ westward of the main island, the top of which is flattened at a depth of about 50-60m (Teixeira et al., 2003). These latter authors point out that the physical barrier effect created by the FN island structure could induce upwelling processes in the insular shelf waters, as observed on the oceanic islands (Thomson, 1981).

The geological structure of the Fernando de Noronha archipelago consists of substrate pyroclastic rocks that were deposited in a subaerial environment and were crossed by a wide variety of alkaline igneous rocks (Almeida, 2006). Fernando de Noronha's volcanism, represented by the rocks of the archipelago which are of strongly alkaline composition - considered to be among the most alkaline of the volcanic oceanic islands' in the world - affects their sedimentary composition, since it is of subsaturated silica (with levels ranging from $34.4 \%$ to $60.8 \%$, corresponding to ankaratrite melilita and alkali trachyte, respectively). However, there is no quartz present in the rocks, despite this being the most abundant material in the earth's crust (Almeida, 2000).

Based on Wildner \& Ferreira (2011) geochronology, the Noronha magmatic province was initially formed of the lighter fractions, giving rise to the Remedios Formation (dated at 8 to $12 \mathrm{Ma}$ ), and thereafter an erosive hiatus (that lasted between 5.0 and 6.0 Ma) followed by the ultrabasic volcanism of the Quixaba Formation (dated between 3.0 and 1.7 Ma) (Almeida, 1955; Almeida, 2000; Cordani, 1970). The sediments on the island and shelf are reduced to coastal, marine and eolic deposits, belonging to the current cycle and other Quaternary cycles, as well as the insular abrasion platform of the archipelago (Almeida, 2000; Teixeira et al., 2003; Barcellos et al., 2016a).

The tropical islands rise from an insular shelf with a diameter of $10 \mathrm{~km}$ and a break around the $100 \mathrm{~m}$ isobath formed by Quaternary glacioeustatic sea level variations. Modern sedimentary biogenic deposits are present on the beaches on the northern side of the island (Mar de Dentro) (Figure 2) as well as in its southern portion (Mar de Fora). The insular shelf is $10 \mathrm{~km}$ in diameter and has an asymmetrical ellipsoid shape, where the archipelago extends northwards. Thus FN's southern shelf is twice as wide (6-7 $\mathrm{km})$ as its northern shelf, which extends for $3 \mathrm{~km}$ out to the shelf break (Teixeira et al., 2003; DHN, 2005; Almeida, 2006; Manso et al., 2011; Barcellos et al., 2011; Barcellos et al., 2016a).

The climate is tropical oceanic (Awi, according to Köppen), with an annual average temperature of $25.4^{\circ} \mathrm{C}$ (Teixeira et al., 2003; Manso et al., 2011). The average annual rainfall for the island is $1,400 \mathrm{~mm}$, with a rainy season (winter) between March and July (the highest rainfall occurring between March and May), and a dry period (summer) between August and February. The tidal regime is mesotidal semi-diurnal, with a range of $2.6 \mathrm{~m}$ during the spring tides and $1.1 \mathrm{~m}$ in the neap tides (DHN, 2005).

The dominant wind regime is southeasterly, with an average speed of $6.6 \mathrm{~m} / \mathrm{s}$, of greater intensity in July and August, while in the summer there is a predominance of moderate winds associated with the currents from the southeast, presenting waves of an average height of $1.13 \mathrm{~m}$ and average period of $13.3 \mathrm{~s}$ at the Conceição, Boldró and Bode beaches, thus characterizing a low energy environment. In the period from January to March, NNE currents occur, giving rise, in the northern part of the main island, to waves with amplitudes of up to $5 \mathrm{~m}$ (16-20s), characterizing a high-energy environment (Manso et al., 2011). In winter, the prevailing SE winds (70\% of the frequency) alternate with easterly winds (25\% of the frequency), the prevailing waves coming from the SE and having a mean height of $1.6 \mathrm{~m}$ at the Sueste beach (Höflich, 1984; Barcellos et al., 2011).

The archipelago is bathed by two important marine currents: the central branch of the South Equatorial Current (CSEC), flowing from $\mathrm{E}$ to $\mathrm{W}\left(\approx 30 \mathrm{~cm} \cdot \mathrm{s}^{-1}\right)$ between the surface and a nominal depth of $100 \mathrm{~m}$, responsible for the clear, warm water (around $28^{\circ} \mathrm{C}$ ), with a salinity of 36 PSU; and the South Equatorial Undercurrent (SEUC), flowing in the opposite direction $(\mathrm{W}-\mathrm{E})\left(\approx 20 \mathrm{~cm} \cdot \mathrm{s}^{-1}\right)$, from 40 to 150 meters deep (Edwards and Lubbock, 1983; Eston et al., 1986; Stramma and England, 1999). The CSEC is located between the SEUC $\left(3^{\circ} \mathrm{S}-5^{\circ} \mathrm{S}\right)$ and the South Equatorial Counter Current $\left(6^{\circ} \mathrm{S}-9^{\circ} \mathrm{S}\right)$ (Stramma and England, 1999; Assunção et al., 2016). 

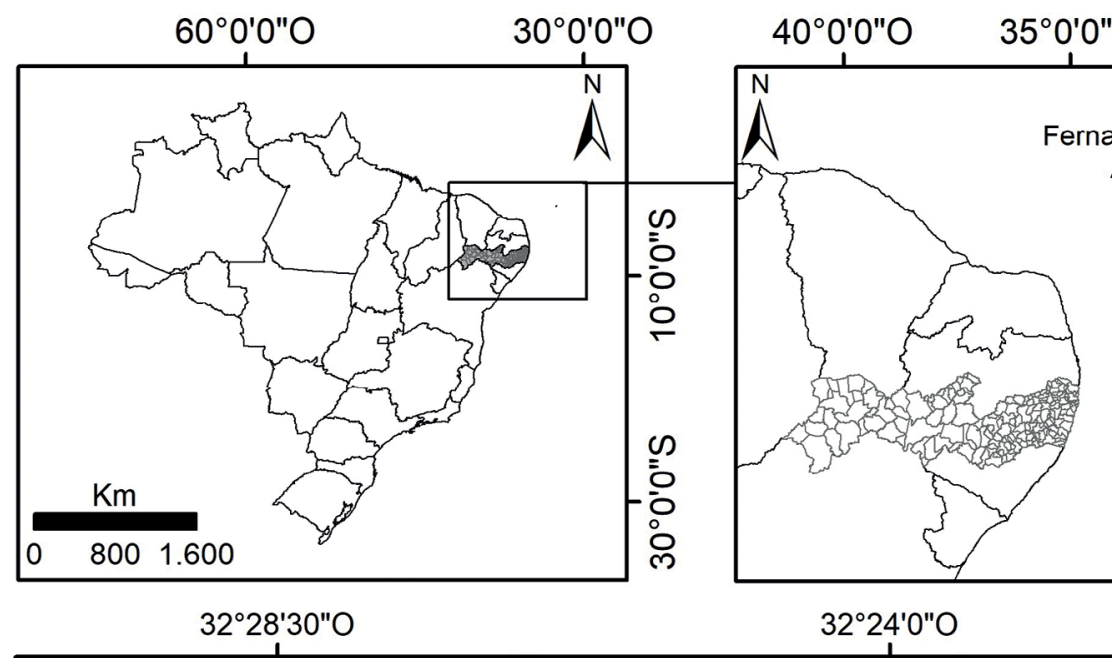

ernando

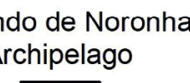

0
0
0
0
0
0
0
0
0
0
00
0
0
1

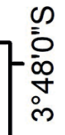

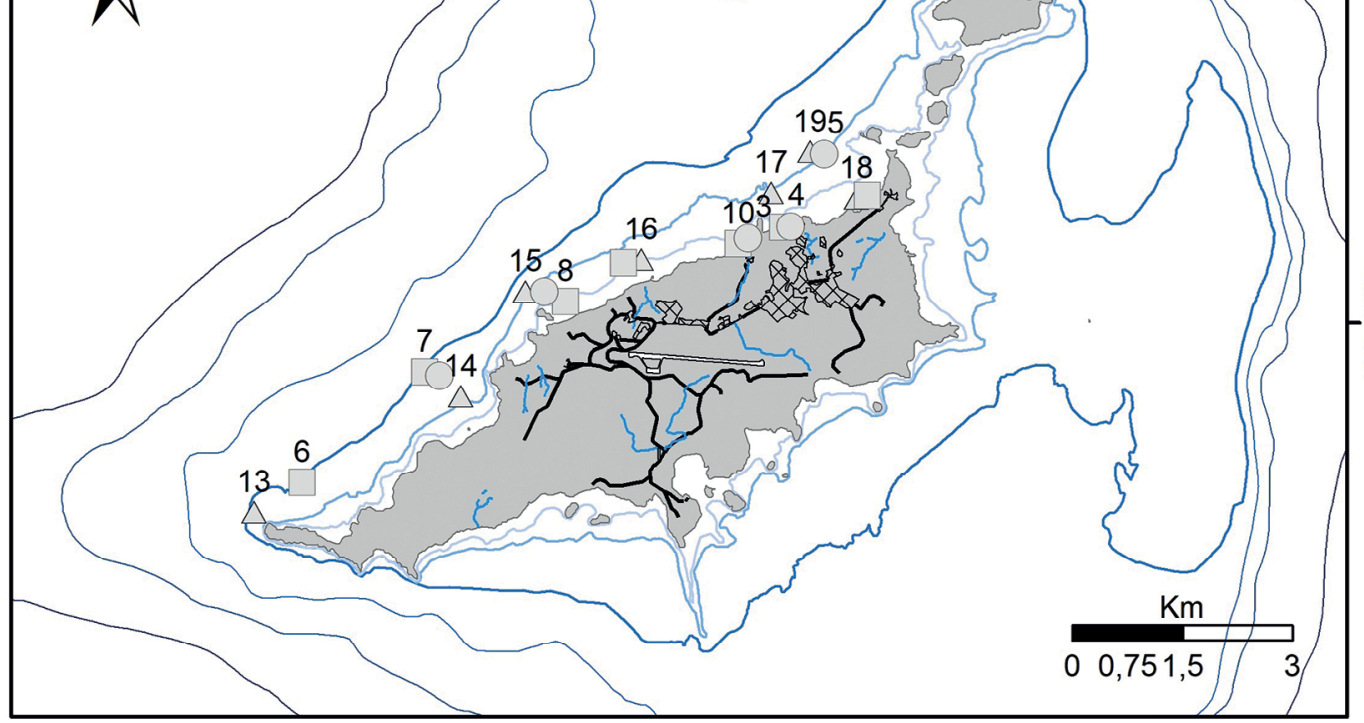

\section{Legends}

Dry season 2013 (1 to 5)

Rainy season 2014 (6 to 12)

$\triangle$ Dry season 2014 (13 to 19)

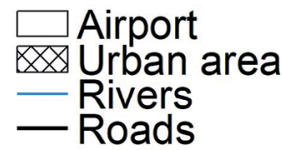

Datum: WGS1984

Data source:

DHN, 2005;

Assis et al., 2014 


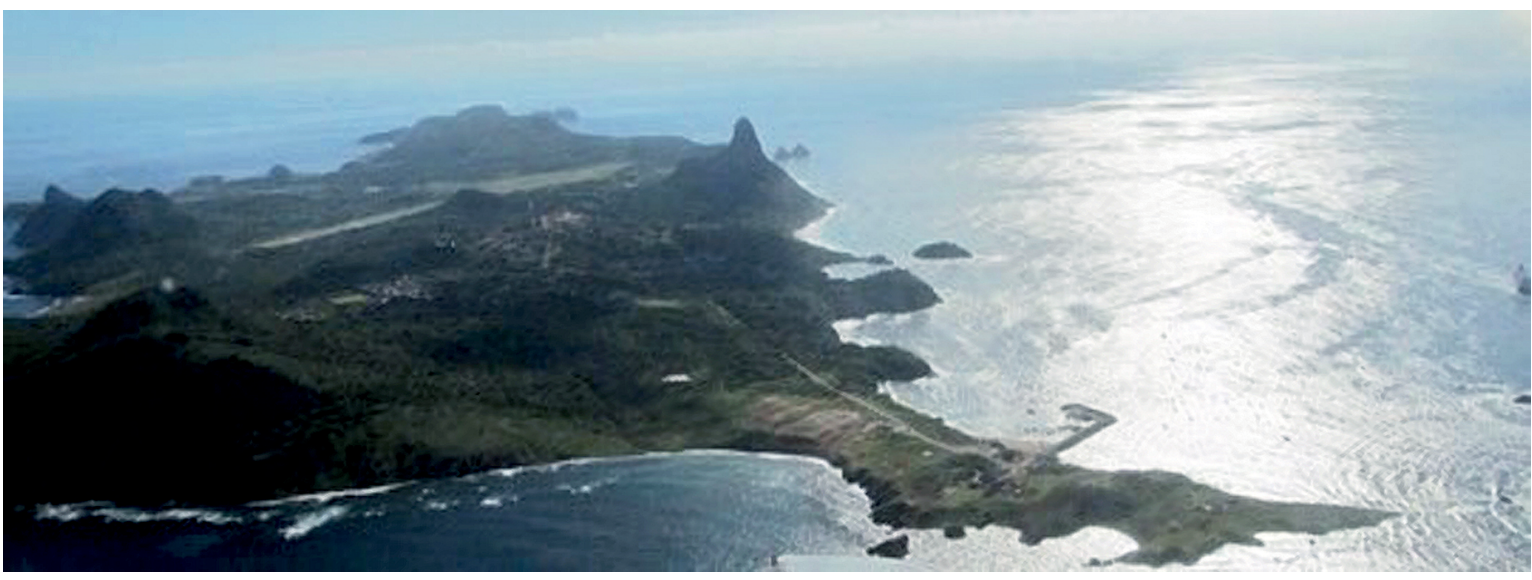

Figure 2. Aerial view of the FN islands, the "Mar de Fora" coast and adjacent insular shelf (Photographer: Roberto L. Barcellos, March/2011).

The water column structure that surrounds the FN archipelago usually presents a profile characteristic of South Atlantic waters, with the presence of the following water masses: Tropical Surface Water (TSW), South Atlantic Central Water (SACW), Antarctic Intermediate Water (AAIW) and the North Atlantic Deep Water (NADW) (Stramma and England, 1999; Assunção et al., 2016). The nutrient dynamic and thermohaline water column properties of the FN insular shelf are, therefore, directly influenced by this vertical and horizontal distribution of these regional water masses and currents, as has recently been confirmed by Travassos et al. (2016) and Assunção et al. (2016). In the former research it was observed that the levels of organic matter, both from natural sources and of anthropogenic origin, are low in the Mar de Dentro water column. The latter also indicates a nutritional deficit, confirming the oligotrophic characteristics of the region, characterized by the presence of Tropical Surface Water (TSW: $28^{\circ} \mathrm{C} / 36 \mathrm{PSU}$ ).

\section{SAMPLING PROCEDURES AND ANALYTICAL METHODS}

Nineteen bottom sediments samples were collected, with a Van Veen grab sampler, in 3 seasonal field surveys, covering the dry season of 2013 (Dec/13) and the rainy and dry periods of 2014 (Jul/14- Nov/14), along the adjacent island shelf on the northern coast of the Fernando de Noronha archipelago.

The grain size analyses were performed in accordance with the sieving and pipetting techniques described in Müller (1967) and Suguio (1973) and the data were processed in accordance with Folk and Ward's (1957) statistical parameters and Shepard's (1954a) facies diagram. The coarse fraction analysis was carried out in accordance with the proposal of Shepard and Moore (1954b), as modified by Hubert (1971), Mahiques (1987) and Mahiques et al. (1998). Morphometry analyses were conducted to assess the degree of rounding according to the table given by Russell et al. (1973 in Müller, 1967) and the degree of sphericity according to the method using Catacosinos's tables (1965) for lithoclastic grains.

For the elemental and isotopic carbon fractions (C and $\delta^{13} \mathrm{C}$ ) and nitrogen $\left(\mathrm{N}\right.$ and $\left.\delta^{15} \mathrm{~N}\right)$, the samples were decarbonated and processed according to the technique described by Hedges and Stern (1984) and were later placed in an elemental analyzer (EuroVector ${ }^{\circledR}$, EA 3000) coupled to an IRMS mass spectrometer (Thermo ${ }^{\circledR}$, Delta V Advantage). The calcium carbonate $\left(\mathrm{CaCO}_{3}\right)$ and total organic matter (TOM) contents were obtained by the weight difference between the dry samples before and after reacting with $\mathrm{HCl}$ and $\mathrm{H}_{2} \mathrm{O}_{2}$, respectively, both with $10 \%$ dilution (Carver, 1971). Phosphorus concentrations were determined by the method of Williams et al. (1976), being measured by the colorimetric method of Grasshoff et al. (1983) as modified by Burrus et al. (1990) and described by Pardo et al. (2004).

The Spearman's nonparametric correlation (rs) was performed using the Excel 2013 software. Principal component (PCA) and group (cluster) analyses were performed using Primer 6 software. The spatial distribution of the parameters studied represented in this article's figures was described using the ArcMap 10.3 software.

\section{RESULTS AND DISCUSSION}

The sediments' physical properties, composition and geochemistry results obtained by laboratory analysis are given, respectively, in Appendix 1 and 2, the data 
treatment by Spearman correlation (rs) in Appendix 3, and the results obtained by the coarse fraction analysis in Appendix 4 and 5.

\section{SPATIAL-TEMPORAL DISTRIBUTION AND COMPOSI- TION OF THE SEDIMENTS}

In all the seasons the adjacent inner shelf of the Fernando de Noronha archipelago presents textural sandy facies (Shepard, 1954). In general, mean diameter (Figure 3 ) varied from very fine sand to granule (Folk and Ward, 1957), whereas in the rainy season there is fine to coarse sand, with a prevalence of fine sand. In dry periods the contents vary from granules to very fine sand, but with the predominance of fine sand. The composition of the sedimentary fractions showed an absence of clay from the samples, though silt was observed in 12 of them. The sand content averaged $97.6 \%$, characterizing a homogeneous environment, excepting the samples from sites 1 and 11, which presented higher levels of gravel, $89.29 \%$ and $24.44 \%$, respectively. This low sedimentary variation at the sites studied shows that the environments are submitted to the same geological agents as the energy of the waves and tides, independently of the seasonal periods, allowing selection to occur in a population within a certain grain size range (Sahu, 1964). Despite this homogeneity the differences between the SW samples are clear (STs: 1, $6,11,17$ and 18), being composed of coarser gravelly sediments than the central and NE samples, consisting mainly of fine sands ( $\approx 0.13 \%$ of gravel) (Figure 4$)$.

The sorting (Figure 5) ranged from poorly sorted to very well sorted, with a predominance of well sorted grains, regardless of the seasonal period, showing the relative sedimentary homogeneity of this collection of 19 samples. This character is typical of open shelf areas, subjected to a high wave energy dynamics. The exception occurs in the SW samples (STs: 1, 6, 11, 17, 18) that, due to the higher gravel content, $(\approx 28.6 \%)$ were classified as poorly sorted. Similarly, in a seasonal sedimentary study on the Sueste beach and bay, located on the island's southern coast (Mar de Fora), Barcellos et al. (2011) and Barcellos et al. (2016a) observed that in all the periods analyzed, the grains were composed of sand, with a predominance of well to moderately sorted fine sands.

Based on the assertion that the beaches are accumulations of loose material, located in the boundary areas of the wave action (King, 1972), the observed sedimentary results were compared with those of the study conducted by Manso et al. (2011). This latter study undertaken on the beaches adjacent to the central and NE northern FN shelf, presents similarities in its sorting and mean diameter values to those of our collection of samples.

First, these results indicate that the composition of the insular shelf sediments and the beaches is very similar, probably due to the onshore-offshore seasonal transport from the beaches to the shelf and vice-versa by wave action. In the second place, the flattened, less steep and shallow $(<19.0 \mathrm{~m})$ bottom morphology of the central (Sts 4, 7, 16 - Cacimba do Padre) to NE portions of FN's northern shelf (see Figure 1), may facilitate the deposition and transport of bioclastic fine sands. These sediments are observed on both the inner shelf and beaches, indicating a common origin, probably being composed of autochthonous plus palimpsest particles. Finally, the corals and calcareous algae banks, linear platforms and submerged volcanic basement outcrops may also act as sandy sediment traps in this area, northeastwards from St 4 (Dois Irmãos hill).

The spatial sedimentary distribution reflects the local influences of waves, longshore and insular shelf currents, tides, bottom morphology and the location of biogenic and lithoclastic sediment sources. The Mar de Dentro is subject to energetic swells from the NNW, N and NNE each year in the spring-summer season, constantly reworking the biogenic sands. The NNW swells generate longshore currents from SW to NE. While, in the opposite direction, flow the currents formed by the N/NNE swells and also the shelf currents generated by AESC (E-W) (Teixeira et al., 2003). Thus, most of the time, the currents and therefore, the sediment transport, probably follow the NE-SW pattern, as pointed out by Manso et al. (2011). Although, seasonally no differences in grain size parameters was observed among the three studied periods, even with the more energetic hydrodynamic conditions observed in the summer. The spatial distribution of sampling stations and the scarce number of samples (19) could not reflect this seasonal alternation in dynamics, since the biogenic sands are in general relict and constantly reworked by waves in summer period and deposited in the subsequent winter.

Further, the absence of sandy beaches in the SW portion of the island, characterized by $50-80 \mathrm{~m}$ high clifflined coasts and rounded gravel basaltic deposits, also agrees with the results observed on the adjacent shelf. The sampling stations $1,6,11,17$ and 18 are situated on biogenic gravel and coarse sand of rock fragments and calcareous algae (see Figure 4) There are various reasons for this character: the more irregular shelf, bottom and coastal 


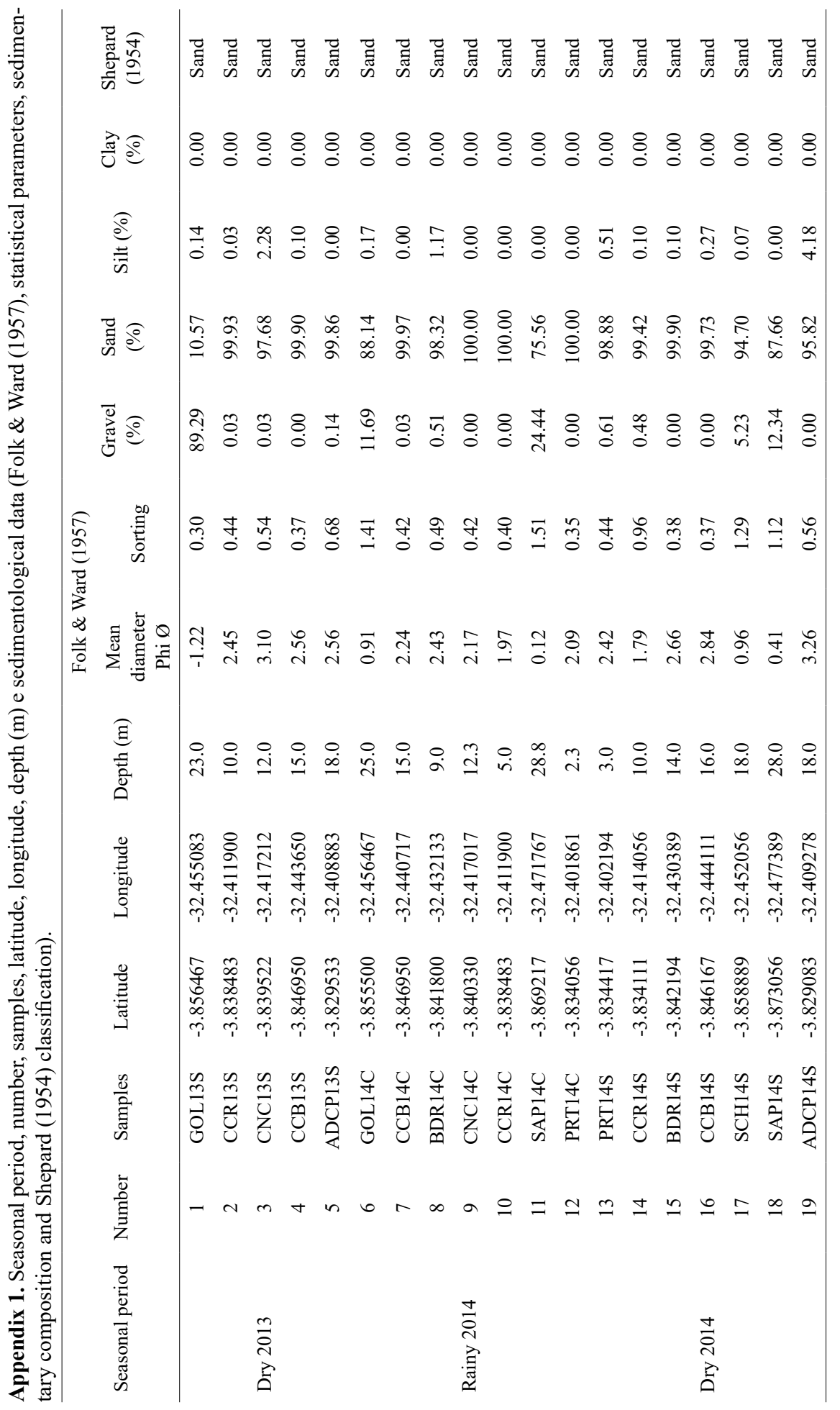









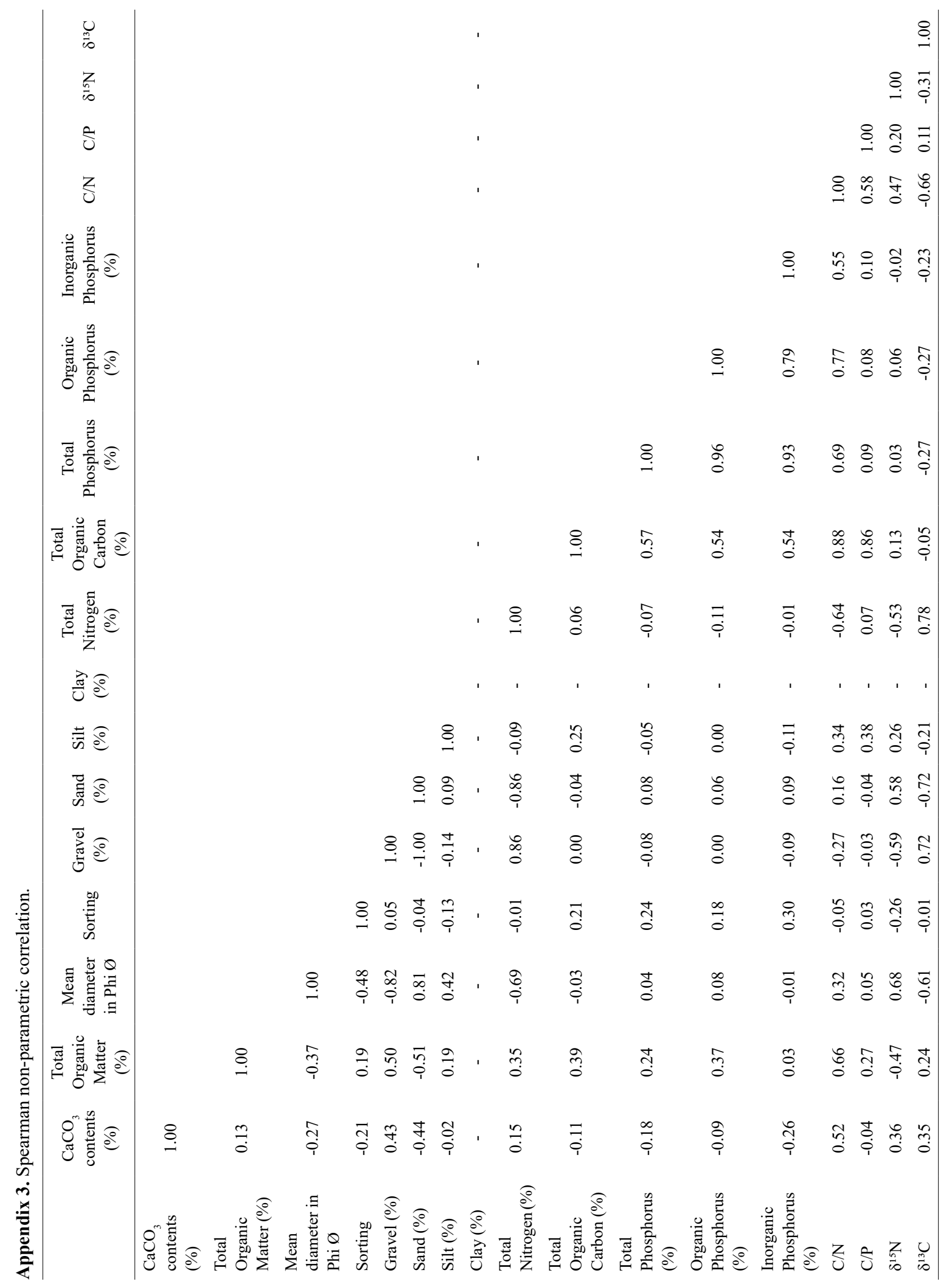




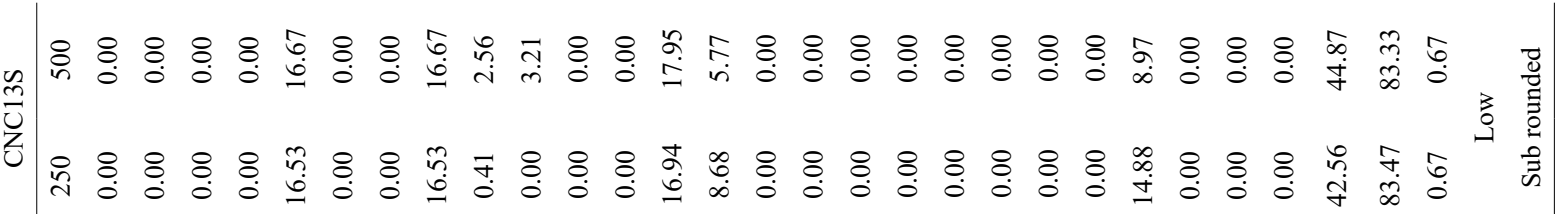

m

J

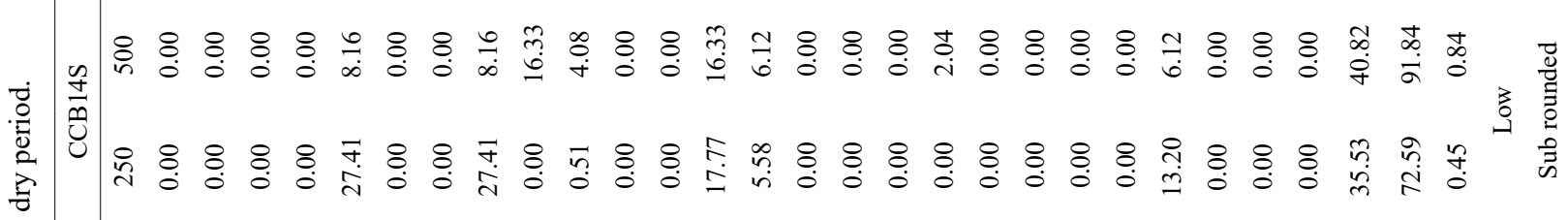

臭

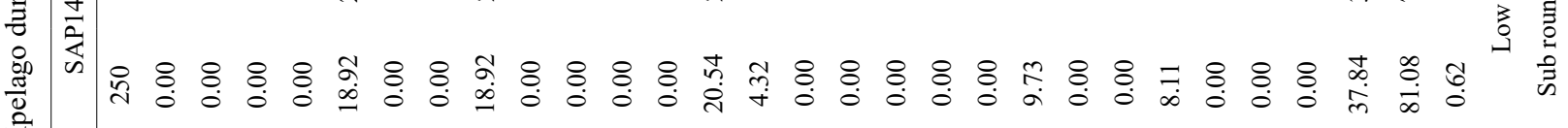

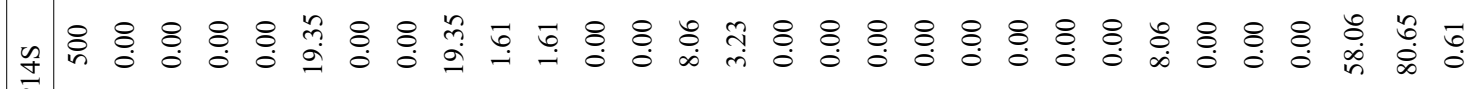

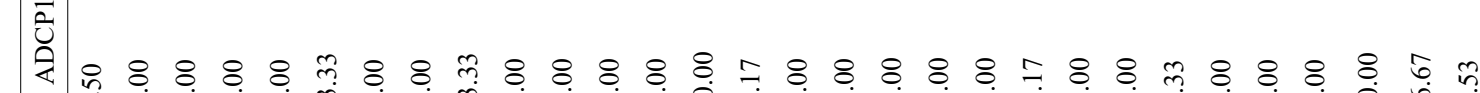

울

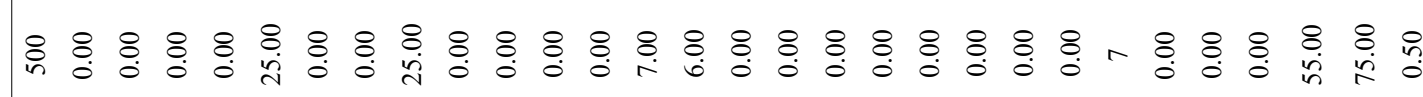

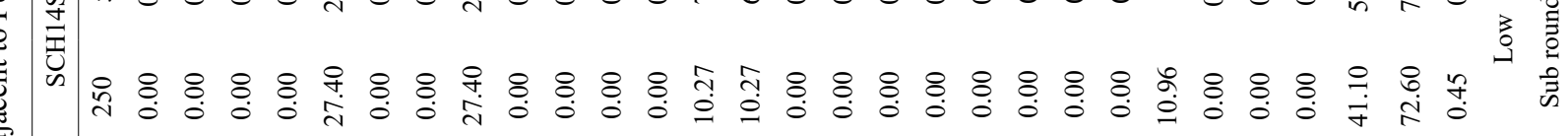

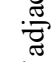

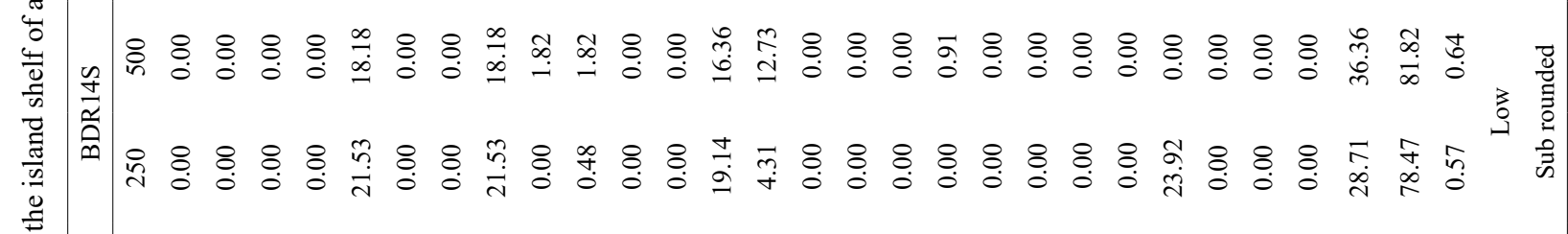

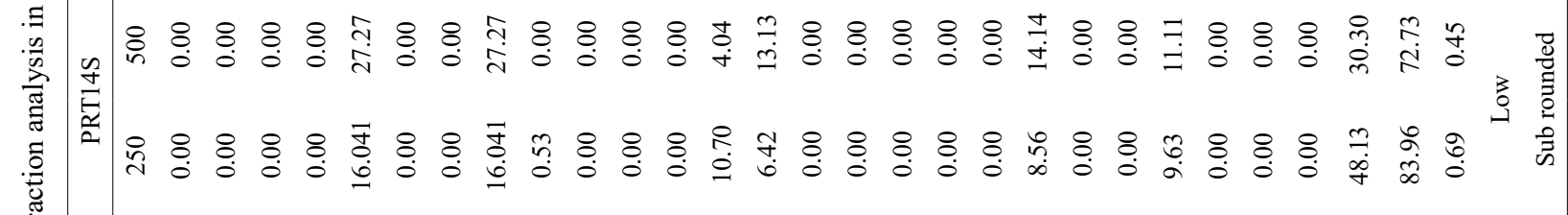




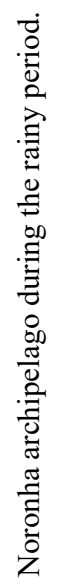

贾

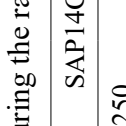

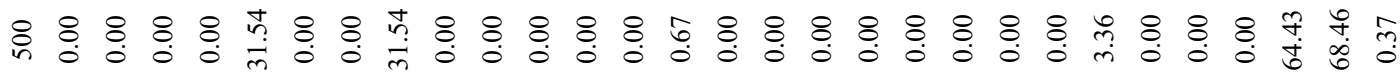

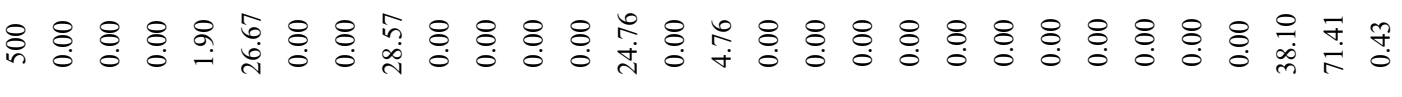

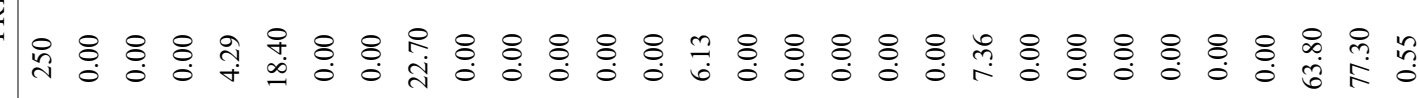

$\frac{0}{2}$

4

भ̊.

8.0

กิ

$\stackrel{8}{\circ}$

$\stackrel{8}{8}$

$\stackrel{8}{8}:$

$\stackrel{\infty}{\infty}$

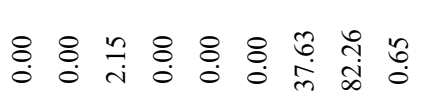

○ 0 ○

$\frac{8}{8} \frac{2}{8}$

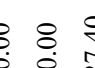

舟 8

8 운

8.8

¿.

$\frac{\sqrt{4}}{5}$

i

$\stackrel{8}{8}: \stackrel{8}{0}$

$\stackrel{8}{8}:$

ڤ \& \& \&

\& \& \& \& \& $\%$ \&

U

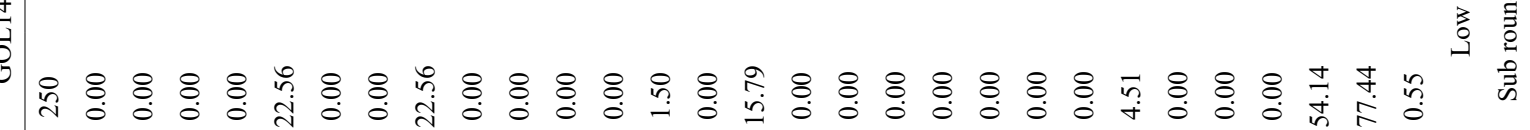

\& \& \& \& I

m

$\cong$

.

$\frac{n}{2}$

产

苛

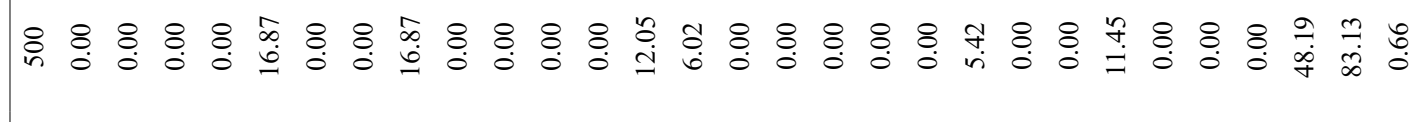

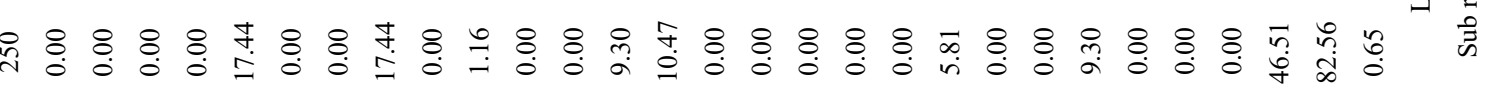

灾

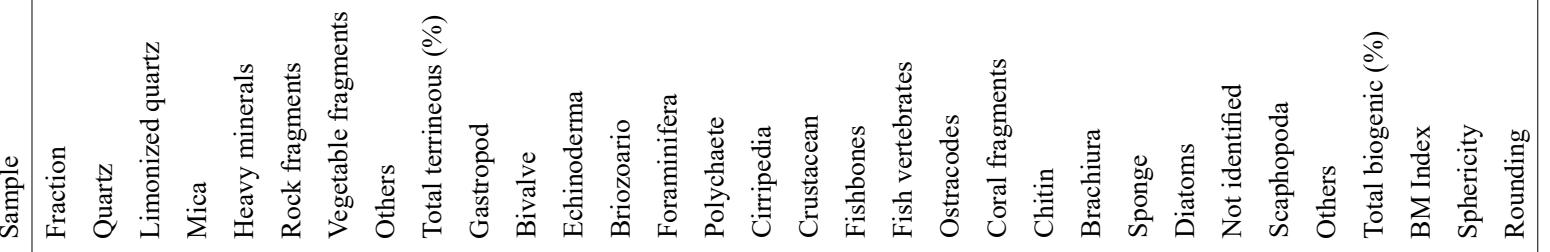




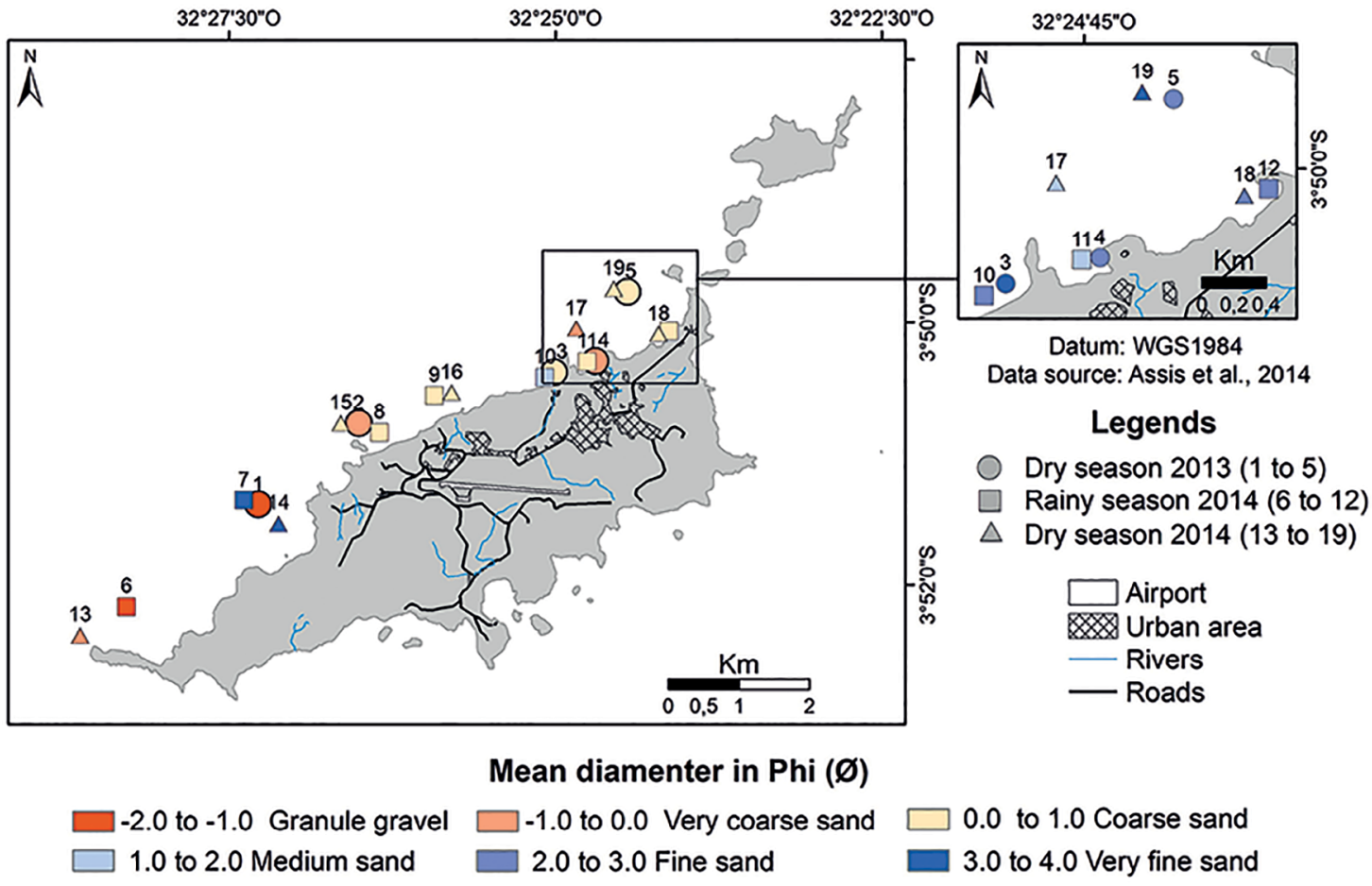

Figure 3. Mean diameter (in Phi) at the sediment sampling stations.

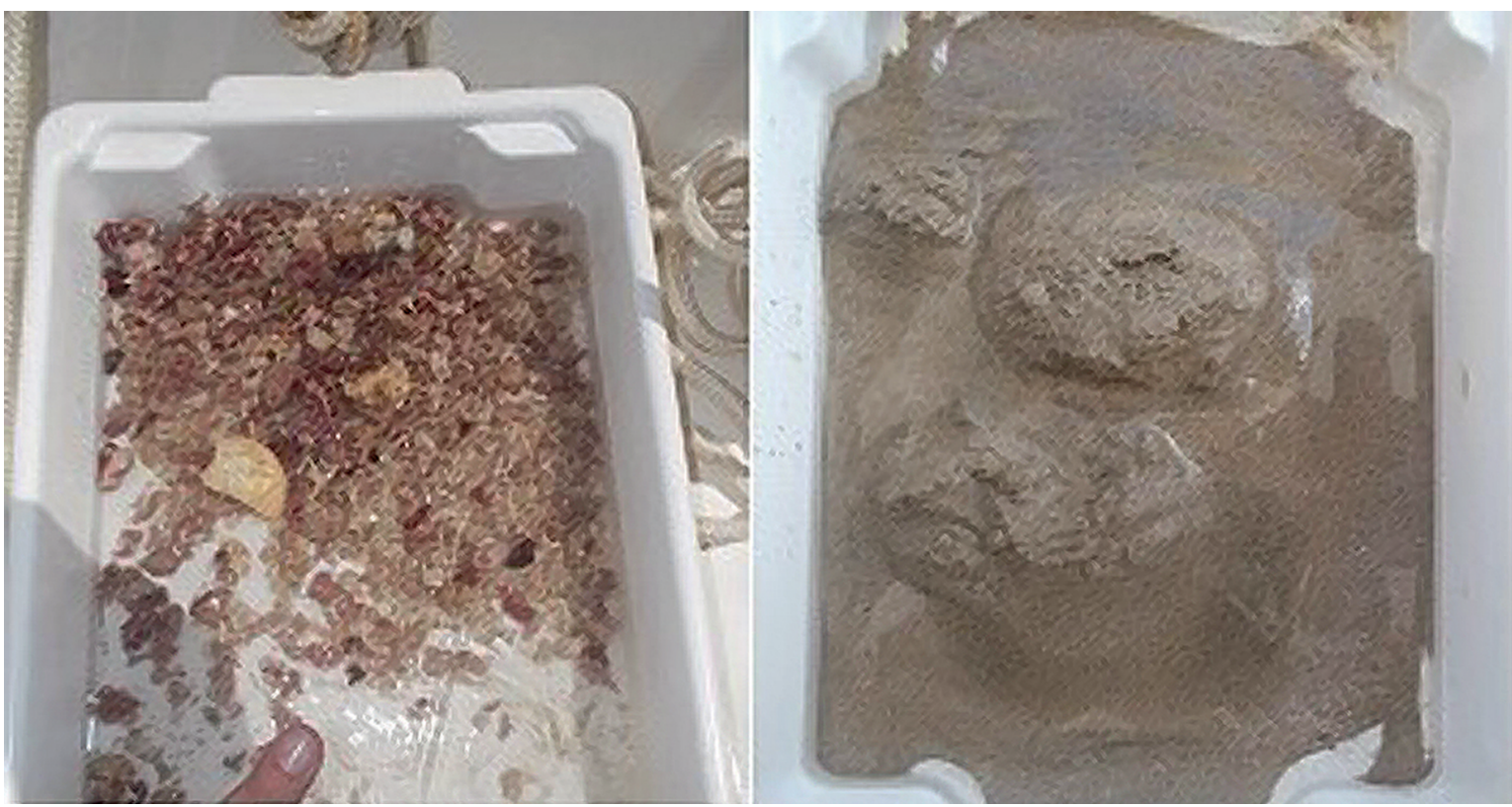

Figure 4. Gravelly sediments (St 11) (left) and sandy sediments (St 7) from FN's north shelf. 


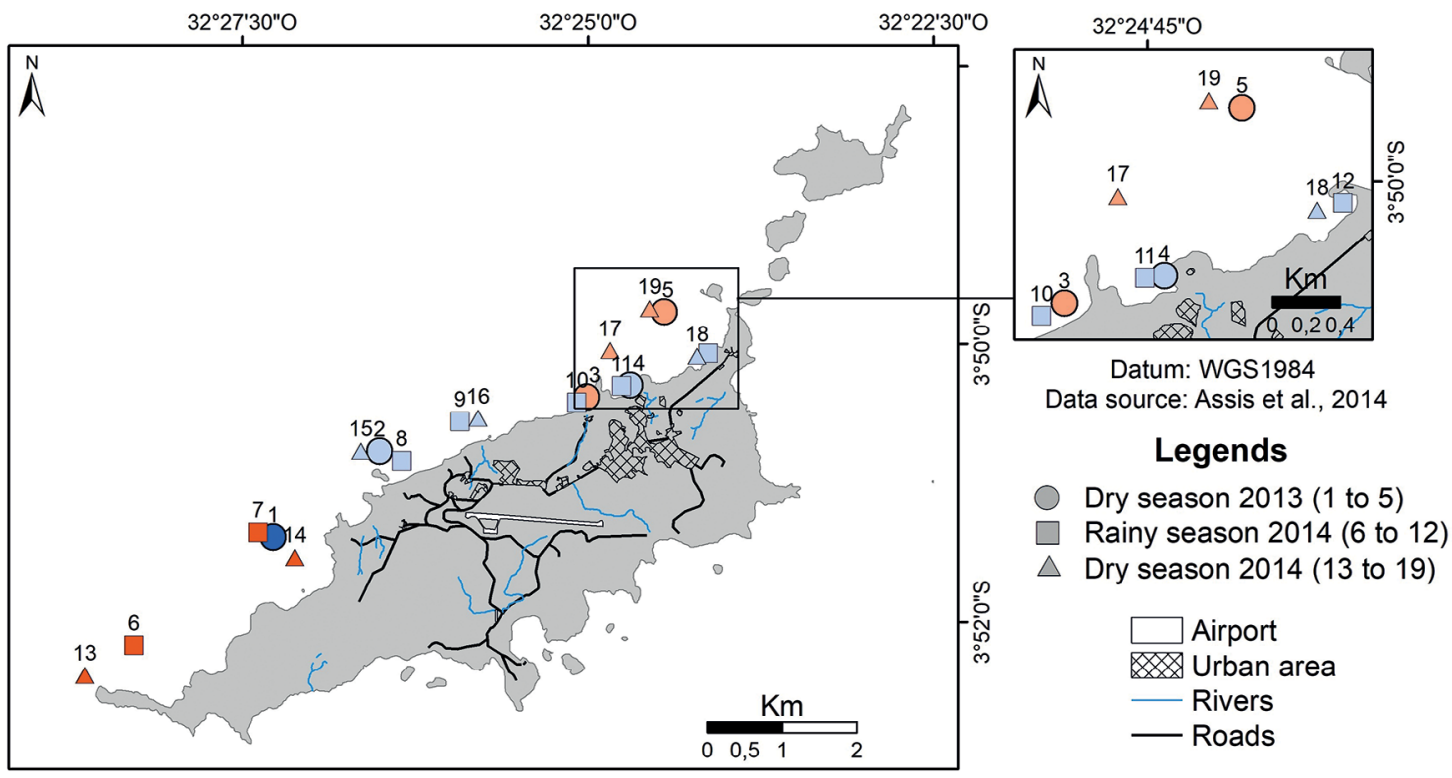

\section{Sorting of sediments}

$<0.35$ - Very well sorted

0.35 to $0.5-$ Well sorted
0.5 to 1.0 - Moderately sorted

1.0 to 2.0 - Poorly sorted

Figure 5. Sorting of the sediments at the sampling stations.

morphology, added to the modern current pattern and a negative imbalance in the sedimentary volume of FN's northern beaches (DHN, 2005; Manso et al., 2011).

The follow bathymetric detailed description was based in the interpretation of Fernando de Noronha nautical chart by Navy Department of Hydrography and Navigation (DHN, 2005) and the DTM generated by Brazilian Geological Survey (CPRM, 2014).

The presence of headlands such as Dois Irmãos hill (Sts $4,7,16$ ) and the western promontory of Sancho beach, associated with a bottom depression and an increase in shelf depth and steepness southward (DHN, 2005) (CPRM, 2014), may induce a transfer of inner shelf sediments by dispersion with partial loss of this material to deeper and more open areas of the insular platform, very narrow and scarped at this point (1.5-2.0 km wide). This flux of sandy sediments from the NE extends as far as the Sancho beach. However, the greater depths southward ( $>23 \mathrm{~m}$ : that avoid more vigorous reworking by wave action) and another ravine-like depression at the entrance of Golfinhos bay ( $\mathrm{St}$ 1) might explain the relative decrease in sandy sediments and the increase of gravel content in SW shelf samples and coastal deposits. This process is represented in the qualitative circulation model for FN shelf (Figure 6).

This irreversible loss of the sandy sedimentary material in these two potential sediment hot-spots (Dois Irmãos and Golfinhos) (Johnson and Baldwin, 1996) may be compensated for by the local biogenic primary productivity, since the sedimentation on the whole FN shelf is essentially of biogenic origin (Barcellos et al., 2016a). This hypothesis, however, has not been supported by any complementary studies.

The results of the coarse fraction analysis (CFA) and morphoscopy are described in Table 1, and the detailed description for the CFA is tabled in the Appendices 4 and 5 .

For the selected sampling stations, in the rainy season, in both fractions $(0.250 \mathrm{~mm}$ and $0.500 \mathrm{~mm})$, all the samples showed a positive marine biogenic index (MBI) (Mahiques et al., 1998), indicating a greater marine influence in the deposition (Figure 7). For the samples in the rainy season, only $14.3 \%$ in the $0.500 \mathrm{~mm}$ fraction had a MBI higher than $0.250 \mathrm{~mm}$ fraction. Similar to the rainy season, in the dry season, all selected samples stations, in both fractions, showed a positive MBI, although the 


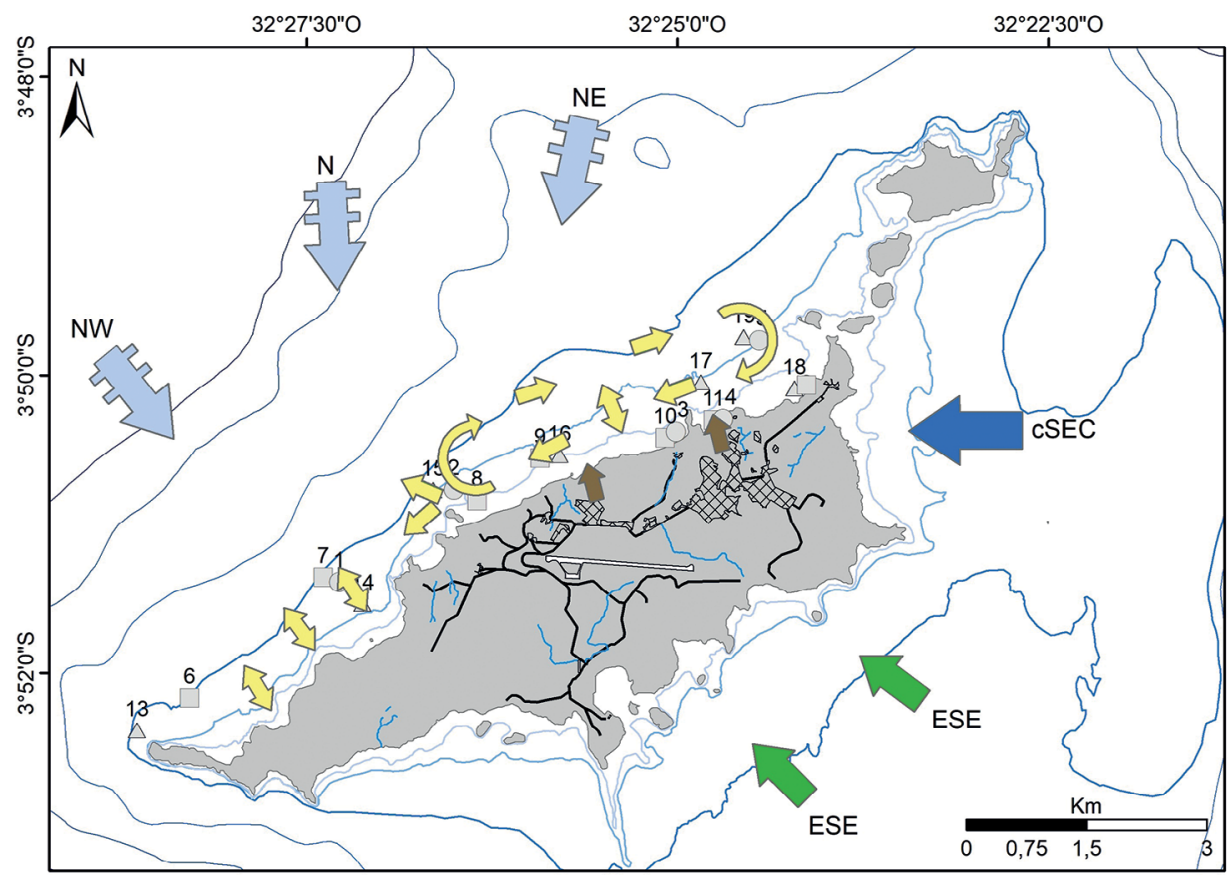

Datum: WGS1984

Data source:

DHN, 2005:

Assis et al., 2014

\section{Legends}

\begin{tabular}{l}
$\square$ Airport \\
\hline Urban area \\
- Rivers \\
$\square$ Roads \\
$\square$ Isobath -10 \\
$\square$ Isobath -20 \\
$\square$ Isobath -30 \\
$\square$ Isobath -50 \\
$\square$ Isobath -100 \\
$\square$ Isobath -500
\end{tabular}

Circulations systems in the island shelf of Fernando de Noronha Archipelago

central South Equatorial Current $\square$ Swell direction $\square$ Trade winds Antropic inputs $\square$ Sedimentary circulation

Figure 6. Qualitative model of circulation based on the sedimentary characteristics, sources and physical processes.

Table 1. Morphoscopy and coarse fraction analysis (MBI: Marine Biogenic Index (Mahiques et al., 1998)).

\begin{tabular}{|c|c|c|c|c|c|c|c|}
\hline \multirow[b]{2}{*}{$\begin{array}{l}\text { Seasonal } \\
\text { period }\end{array}$} & \multirow[b]{2}{*}{$\begin{array}{c}\text { Sampling } \\
\text { Stations }\end{array}$} & \multirow[b]{2}{*}{ Lat. (S) } & \multirow[b]{2}{*}{ Long. (W) } & \multicolumn{2}{|c|}{ Coarse fraction } & \multicolumn{2}{|c|}{ Morphoscopy } \\
\hline & & & & $\begin{array}{c}\text { Fraction } \\
250 \mathrm{~mm}(\mathrm{MBI})\end{array}$ & $\begin{array}{c}\text { Fraction } \\
500 \mathrm{~mm}(\mathrm{MBI})\end{array}$ & Sphericity & Rounding \\
\hline \multirow{7}{*}{ Rainy } & 6 & -3.834056 & -32.401861 & 0.55 & 0.36 & Low & Sub-rounded \\
\hline & 7 & -3.855500 & -32.456467 & 0.55 & 0.49 & Low & Sub-rounded \\
\hline & 8 & -3.846950 & -32.440717 & 0.58 & 0.43 & Low & Sub-rounded \\
\hline & 9 & -3.841800 & -32.432133 & 0.50 & 0.38 & Low & Sub-rounded \\
\hline & 10 & -3.840333 & -32.417017 & 0.65 & 0.66 & Low & Sub-rounded \\
\hline & 11 & -3.838483 & -32.411900 & 0.46 & 0.45 & Low & Sub-rounded \\
\hline & 12 & -3.869216 & -32.471767 & 0.71 & 0.65 & Low & Sub-rounded \\
\hline \multirow{8}{*}{ Dry } & 1 & -3.856467 & -32.455083 & 0.36 & 0.46 & Low & Sub-rounded \\
\hline & 9 & -3.840333 & -32.417017 & 0.67 & 0.67 & Low & Sub-rounded \\
\hline & 13 & -3.873056 & -32.477389 & 0.62 & 0.56 & Low & Sub-rounded \\
\hline & 14 & -3.858889 & -32.452056 & 0.45 & 0.50 & Low & Sub-rounded \\
\hline & 15 & -3.846167 & -32.444111 & 0.45 & 0.84 & Low & Sub-rounded \\
\hline & 16 & -3.842194 & -32.430389 & 0.57 & 0.64 & Low & Sub-rounded \\
\hline & 18 & -3.834417 & -32.402194 & 0.69 & 0.45 & Low & Sub-rounded \\
\hline & 19 & -3.829083 & -32.409278 & 0.53 & 0.61 & Low & Sub-rounded \\
\hline
\end{tabular}






Figure 7. Coarse fraction $(0,500 \mathrm{~mm})$, sample 13 , composed by grains mainly of bioclastic nature.

$62.5 \%$ for the samples in the $0.500 \mathrm{~mm}$ fractions had a MBI higher than in $0.250 \mathrm{~mm}$ fraction. In all the samples analyzed, the terrigenous material is composed of rock fragments and heavy minerals, because there is no quartz in Fernando de Noronha's basement rocks there is none in the sediments either (Manso et al., 2011; Santos, 2002).

The results of the fractions analyzed $(0.500 \mathrm{~mm}$ and $0.250 \mathrm{~mm}$ ) were different from those presented by Pilkey et al. (1967). According to these latter authors, the bioclastic fragments are more commonly found in the $0.500 \mathrm{~mm}$ $(1 \varphi)$ fraction than in the $0.250 \mathrm{~mm} \mathrm{(2 \varphi )}$ one. However, in the results for the platform adjacent to FN the $2 \varphi$ fraction has a greater quantity of biogenic particles due to the bioclastic nature of the sediments. This bioclastic composition is similar to that observed by Barcellos et al. (2011, 2016a) for FN's southern coastal region. Whereas the sediments of the bay and the beach were composed of carbonate materials in all seasons, the MBI had a greater $0.250 \mathrm{~mm} \mathrm{(2} \varphi)$ fraction. For the northern coastal beaches located adjacent to the shelf region studied, Manso et al. (2011) and Valença et al. (2005) observed a sediment composition similar to that found in this study, with the presence of fragments of coralline algae, corals, brachiopods, foraminifera and arthropods. This could also indicate fluxes of material between the shelf and the beaches.

Based on all organisms observed on sandy fraction (appendices 4 and 5) has showed that the foraminifera had the most part of the MBI in the both fractions $(0.250 \mathrm{~mm}$ and $0.500 \mathrm{~mm}$ ), and in the dry season, this percentage ranges from $2.7 \%$ to $17.95 \%$ for the $0.250 \mathrm{~mm}$ fractions, and ranges from $10.0 \%$ to $20.54 \%$ in the $0.500 \mathrm{~mm}$ fraction. The port's area showed the lowest percentages of the foraminifera in the dry seasons, and in the rainy season, there was no presence of foraminifera. The foraminifera are a sensitive indicator for variations in the environmental conditions, from anthropic or natural sources (Murray, 2006) and widely used as bioindicator for the quality of coastal areas conditions (Alve, 1995; Yanko et al., 1998; Dimiza et al., 2016a, 2016b; Frontalini and Coccioni, 2011). In pristine environments, salinity, temperature, organic matter, dissolved oxygen affects the foraminifera, but the Fernando de Noronha's port area, are susceptible to the anthropic stressors, including heavy metals and polycyclic aromatic hydrocarbons (PAHs). However, the absence of the tests could be more probably linked to the local dynamics and no preservation than to the human stressors influences (Frontalini \& Coccioni, 2011; Martins et al., 2013, 2015a, 2015b, 2016; Dijkstra et al., 2017).

Low grain sphericity and few sub-rounded particles were observed, by season, as was also found by Manso et al. (2011). Roundness indicates that the grains have considerable maturity as transported material (Barros et al, 2007). The low sphericity of the terrigenous sedimentary material reflects the insular sources proximity, the low transport and, consequently, the low maturity of the grains. It occurs due to the volcanic origin of the rock fragments present in situ.

\section{SEDIMENT GEOCHEMISTRY}

According to the classification proposed by Larssoneur et al. (1982) for the calcium carbonate content (Figure 8), all the samples collected, regardless of the season, were classified as bioclastic $\left(\mathrm{CaCO}_{3}>70 \%\right)$. Since the lowest content observed was of $73.2 \%$, the predominant values range from $85-90 \%$, with average of $88.3 \%$. These data are corroborated by the MBI, which were positive in $100 \%$ all the samples. A considerable factor lying behind such a bioclastic classification of sediments is that in addition to the high contribution of shells, calcareous algae and coral fragments, limestone rocks are present on Fernando de Noronha (Santos, 2002). These data are corroborated by the MBI, which were positive in $100 \%$ all the samples. A considerable factor lying behind such a bioclastic classification of sediments is that in addition to the high contribution of shells, calcareous algae and coral fragments, limestone rocks are present on Noronha (Santos, 2002). The calcium carbonate values observed in this study are similar to those observed by Barcellos et al. (2011, 2016a) for Sueste bay, in general $>73.8 \%$ and lower than those of the sediments of Rocas Atoll $\left(4^{\circ} \mathrm{S} / 34^{\circ} \mathrm{W}\right)$, consisting entirely of bioclasts (Pereira et al., 2010). 


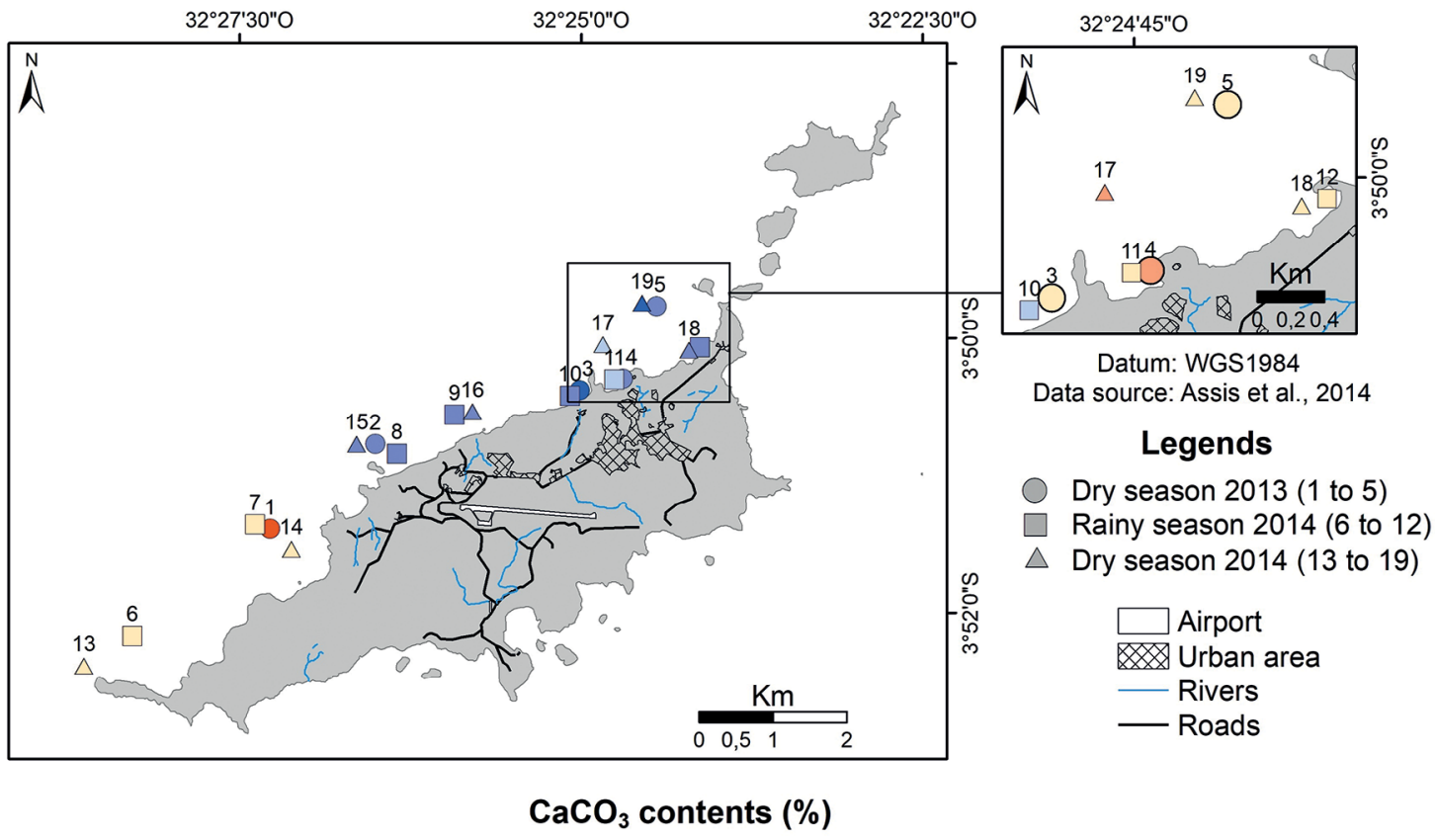

70.0 to $80.0 \square 80.0$ to $85.0 \square 85.0$ to $90.0 \quad \square 90.0$ to $95.0 \quad \square 95.0$ to 100

Figure 8. Calcium carbonate content (in \%) at the sediment sampling stations.

The calcium carbonate content had a positive correlation with the gravel content ( $\mathrm{rs}=0.43)$. The highest values can be observed in the southwestern area, composed by poorly sorted coarse sand and gravel, from marine origin fragments as corals, algaes and mollusks' shells.

The total organic matter content (TOM) (Figure 9) showed no significant seasonal variation, presenting a general average of $1.55 \%$ for all the samples, whose value was lowest $(0.80 \%)$ at St 4 and highest $(2.50 \%)$ at St 8 . These observed values coincide with the data given by Barcellos et al. (2011, 2016a), for whom the total organic matter content remained stable in all the seasons, with similar content to that of the present study (around 2.0\%). According to Assunção et al. (2016), the values of nutrient concentration are quite homogeneous in all the seasons in the waters surrounding the archipelago. Although it's expected that the photic layer are propended to the meteorological variations in this areas, no great spatial differences were observed regarding the nutrient content analyzed in the water column, exhibiting concentrations typical of oligotrophic areas (Vinogradov, 1981; Brown et al., 1989; Philander, 1990; Assunção, et al., 2016).

The total organic carbon content (TOC) (Figure 10), similar to the other sedimentary components, exhibited a fairly uniform character over the seasonal periods, with levels between $0.30 \%$ and $4.29 \%$, and an average of $1.40 \%$. For the 19 samples collected, the organic carbon content of $52.6 \%$ is below $1.0 \%$. The values observed for all the seasonal periods of this study are, in general, low (Romankevich, 1984; Lamb et al., 2006) and 79\% coincide with those observed in a similar study by Barcellos et al. (2016a) in FN's Sueste bay. The remaining samples presented values above $2.0 \%$. According to Travassos et al. (2016), the particulate organic carbon values in the Golfinhos bay (St 1) area observed by the authors (3.69\%) reflect natural sources. As the region is a haven for spinner dolphins (Stenella longirostris), where large groups of more than 500 individuals mate, nurse, defecate and regurgitate, it could serve as a source of autochthonous material (Silva Jr. et al., 2007). In the region adjacent to Cachorro beach (St 14$)$, the observed content $(4.29 \%)$ is attributed to the direct domestic sewage outflow in the area. Similarly in the vicinity of the Boldro and Biboca beaches (St 8 and St 12) that receive wastewater from FN's treatment plants.

Total nitrogen (TN) was detected only in 8 samples (see appendix 2) and the contents are generally low as compared to those given by Romankevich's (1984) data table. The values ranged from $0.04 \%$ to $0.89 \%$, similar to 


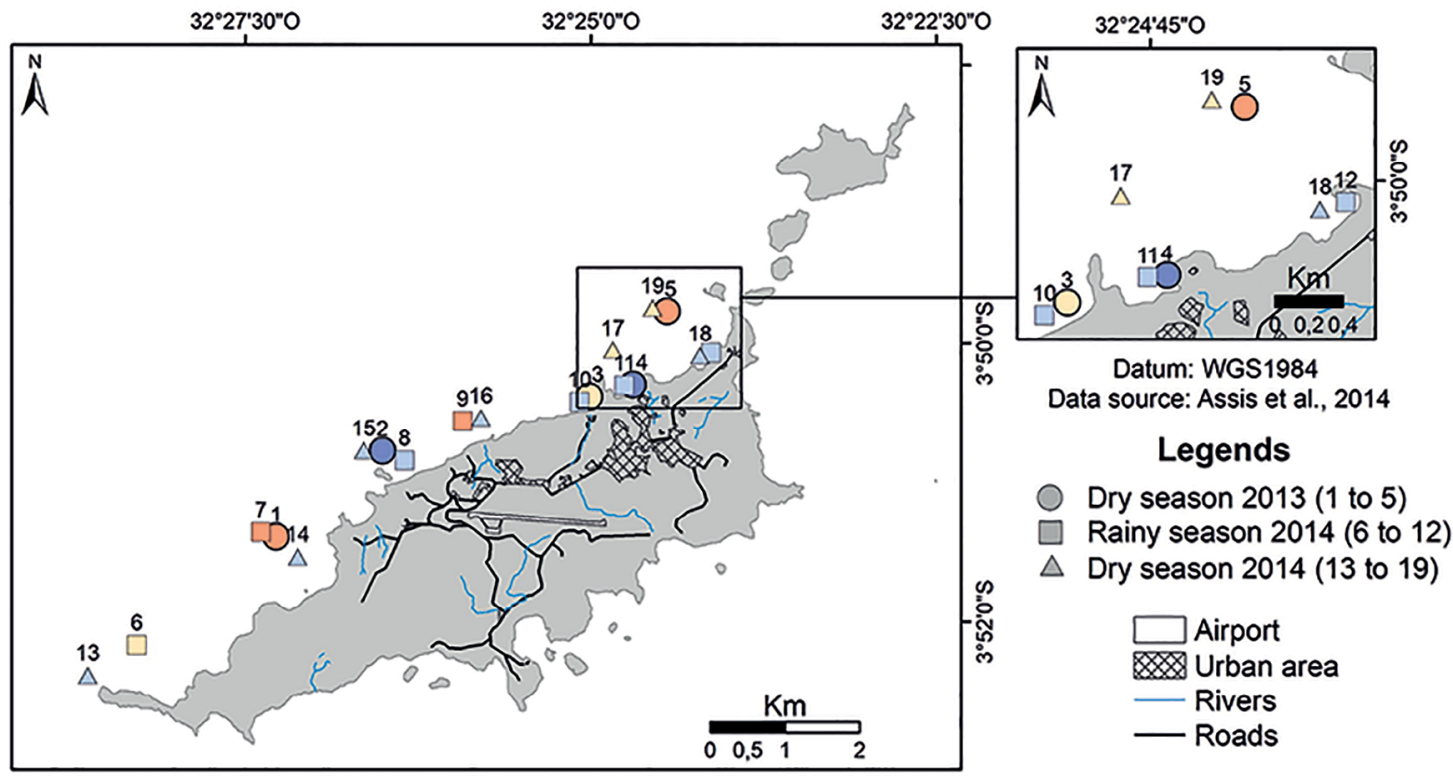

Total organic matter contents (\%)

0.0 to $0.5 \square 0.5$ to $1.0 \square 1.0$ to $1.5 \square 1.5$ to $2.0 \square 2.0$ to $2.5 \square 2.5$ to 3.0

Figure 9. Total organic matter content (TOM in \%) at the sediment sampling stations.
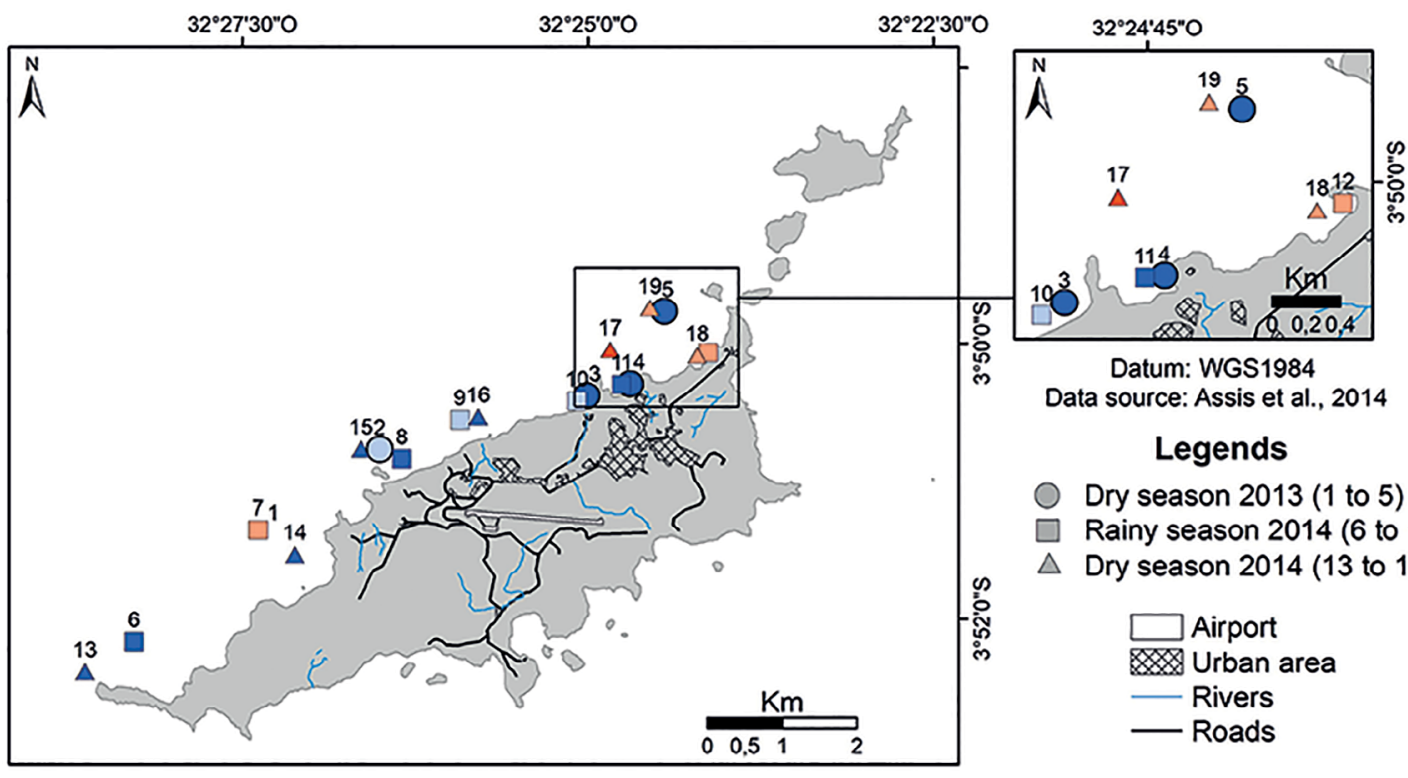

\section{Legends}

Dry season 2013 (1 to 5)

Rainy season 2014 (6 to 12)

$\triangle$ Dry season 2014 (13 to 19$)$

Total organic carbon contents (\%)

0.0 to $1.0 \square 1.0$ to $2.0 \square 2.0$ to $4.0 \square>4.0$

Figure 10. Total organic carbon content (TOC in\%) at the sediment sampling stations. 
those observed by Barcellos et al., 2011 and Barcellos et al. (2016a) in the sediments of the Sueste beach and bay, and by Travassos et al. (2016) for the water column on FN's northern shelf. The highest concentration $(0.89 \%)$ occurs in the region of Golfinhos Bay (St 1), and may reflect the influence of the resident spinner dolphins in the region, and their excreta at the site (Silva Jr. et al., 2007). A different aspect of this study was the positive correlation between the total nitrogen content in the gravel fraction ( $r s=0.864$ ), which differed from the results observed in the Sueste Bay (Barcellos et al., 2016a), and those of Reidhaar et al. (2016) for the saline mangrove swamp on the Saint Croix bay (US Virgin Islands), where nitrogen levels are higher in the finer fractions.

The values of total phosphorus (TP) (Figure 11) were quite homogeneous in the samples, ranging from $0.16 \mu \mathrm{mol} / \mathrm{L}$ to $0.44 \mu \mathrm{mol} / \mathrm{L}$, with an overall average of $0.24 \mu \mathrm{mol} / \mathrm{L}$. These contents are slightly higher than those of some coastal and marine global environments (Barcellos et al., 2005; Frankowski et al., 2002). The most enriched fraction of total phosphorus is composed of organic phosphorus (OP), ranging from $0.01 \mu \mathrm{mol} / \mathrm{L}$ to $0.26 \mu \mathrm{mol} / \mathrm{L}$, with an overall mean of $0.14 \mu \mathrm{mol} / \mathrm{L}$. While the inorganic phosphorus (IP) fractions represent a minor part of the total phosphorus, varying from 0.06 to $0.18 \mu \mathrm{mol} / \mathrm{L}$. The total phosphorus values measured in this study are below the average observed by Reidhaar et al. (2016) for the saline mangrove swamp of Saint Croix bay (average of $1.92 \mu \mathrm{mol} / \mathrm{g}$ ). This is also below the content observed by Ennis et al. (2016) $(2.0 \mu \mathrm{mol} / \mathrm{g})$ for the anthropic low-impact zone of St. Thomas island's coral region (US Virgin Islands). And finally, it is close to the minimum values found for the gulf of Guacanayabo, the gulf of Batabanó and the Sabana Camagüey archipelago, located on the Cuban shelf (Montalvo et al., 2010).

The phosphorus levels observed on the FN shelf probably arise from the leaching of the archipelago's soils, which present high levels of available phosphorus (Nascimento, 2002), mainly due to the island's volcanic origin, which resulted in the production of materials with naturally high levels of phosphorus (Rocha et al., 2005). In fact, Assunção et al. (2016) detected relatively larger proportions of phosphate $\left(\mathrm{PO}_{4}^{3-}\right)$ in the water column, the concentrations of which varied from 0.06 to $0.41 \mu \mathrm{mol} . \mathrm{L}^{-1}$, as compared to the other nutrients studied $\left(\mathrm{NH}_{3}, \mathrm{NO}_{2}^{-}\right.$, $\left.\mathrm{NO}_{3}^{-}\right)$. The same research revealed that silicate $\left(\mathrm{SiO}_{2}\right)$ was the nutrient that showed the highest variation between seasons, as well as the greatest concentrations $(0.76-8.71$ $\mu$ mol.L $\left.L^{-1}\right)$. This higher $\mathrm{SiO}_{2}$ sign could also be related to the leaching of the island's soil and the resulting run-off added to the refractory nature of silicates in the organic matter cycle.

The values of $\delta^{13} \mathrm{C}$ (Figure 12) in the samples ranged from $-24.43 \%$ PDB to $-18.80 \%$ PDB $(\approx-22.17 \%$ PDB $)$. Based on the classifications proposed by Bordovskiy (1965), Chester and Riley (1978), Ruttenberg and Goñi (1997), Stein (1991), Meyers (1997), Lamb et al. (2006) for the origin of sedimentary organic matter in marine environments. About $54.5 \%$ of the FN samples are classified as being of marine to mixed organic matter and the other $45.5 \%$ are classified as being of marine algal composition, indicating the quite frankly marine character of the environment. Compared to the results observed by Barcellos et al. (2011, 2016a), the samples give values similar those for submerged areas of FN's Sueste Bay ( $\left.>-20 \%{ }_{0} \mathrm{PDB}\right)$. On the Pernambuco State coast (NE Brazil), organic matter of marine origin was observed in inner shelf samples collected adjacent to the Jaboatão Estuary inlet $\left(\delta^{13} \mathrm{C}>\right.$ $-20.0 \%$ PDB and $\mathrm{C} / \mathrm{N}$ ratio $<7.0$ ) (Barcellos et al., 2016b). The classification also matches that measured by Reidhaar et al. (2016) for the region of Saint Croix bay.

The $\delta^{15} \mathrm{~N}$ contents showed variations between the seasonal periods analyzed, where the values varied from $0.02 \%$ Air to $7.30 \%$ Air (see Appendix 2), analogously to the levels observed by Barcellos et al. (2011, 2016a). According to Reidhaar et al. (2016), the values coincide with those of the Saint Croix bay region, and are analogous to those given by Ennis et al. (2016) for the coral region of St. Thomas island, both in the US Virgin Islands (West Indies, North Atlantic Ocean) Yamamuro et al. (2003) and Yamamuro and Kamiya (2014) classify these levels as derived from algae present on the shelves. Authors such as Meyers (1997), state that this content cannot be taken as the only parameter for classification of organic matter, due to the overlapping of signatures that the sediment may present, in accordance with the environmental interactions. The $\delta^{15} \mathrm{~N}$ content observed for Golfinhos bay is low (St 1: 1.09\%oAir and St 6: 0.02\%oAir) and could also be related to the excreta of the dolphins and reinforce the enrichment for total nitrogen values determined for the same sediment samples, $0.89 \%$ and $0.11 \%$ of $\mathrm{N}$, respectively. Ogrinc et al. (2005) observed low values of $\delta^{15} \mathrm{~N}$ $(1.80 \%$ Air) on the Adriatic coast and associated them with domestic sewage contamination, as also did Oliveira et al. (2014) (-0.59\%oAir) for the polluted Capibaribe estuary $\left(8^{\circ} \mathrm{S} / 35^{\circ} \mathrm{W}\right)$ located in Recife (PE, Brazil). 


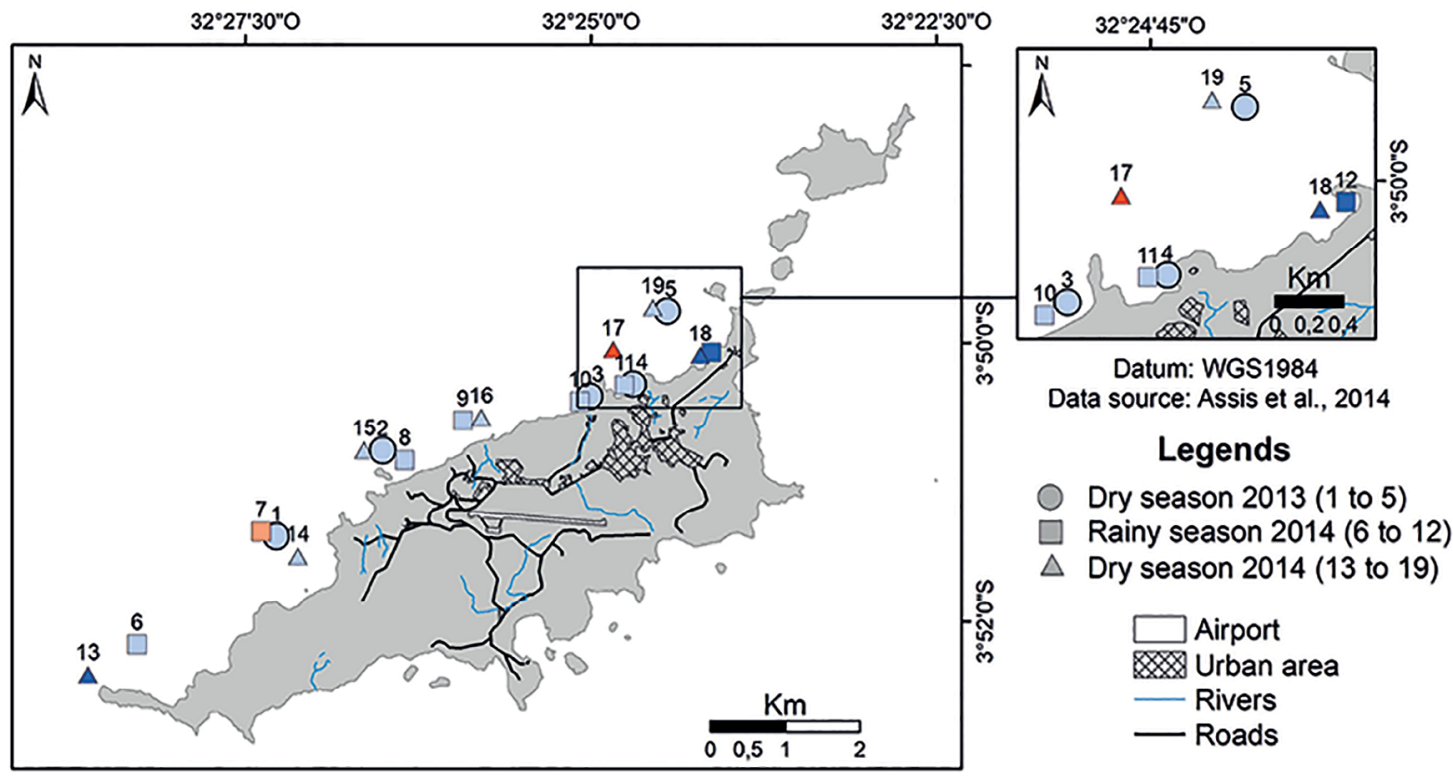

Total phosphorus contents ( $\mu \mathrm{mol} / \mathrm{L})$

0.0 to $0.2 \square 0.2$ to $0.3 \square 0.3$ to $0.4 \square 0.4$ to 0.5

Figure 11. Total phosphorus content (TP in $\mu \mathrm{mol} / \mathrm{L}$ ) at the sediment sampling stations.

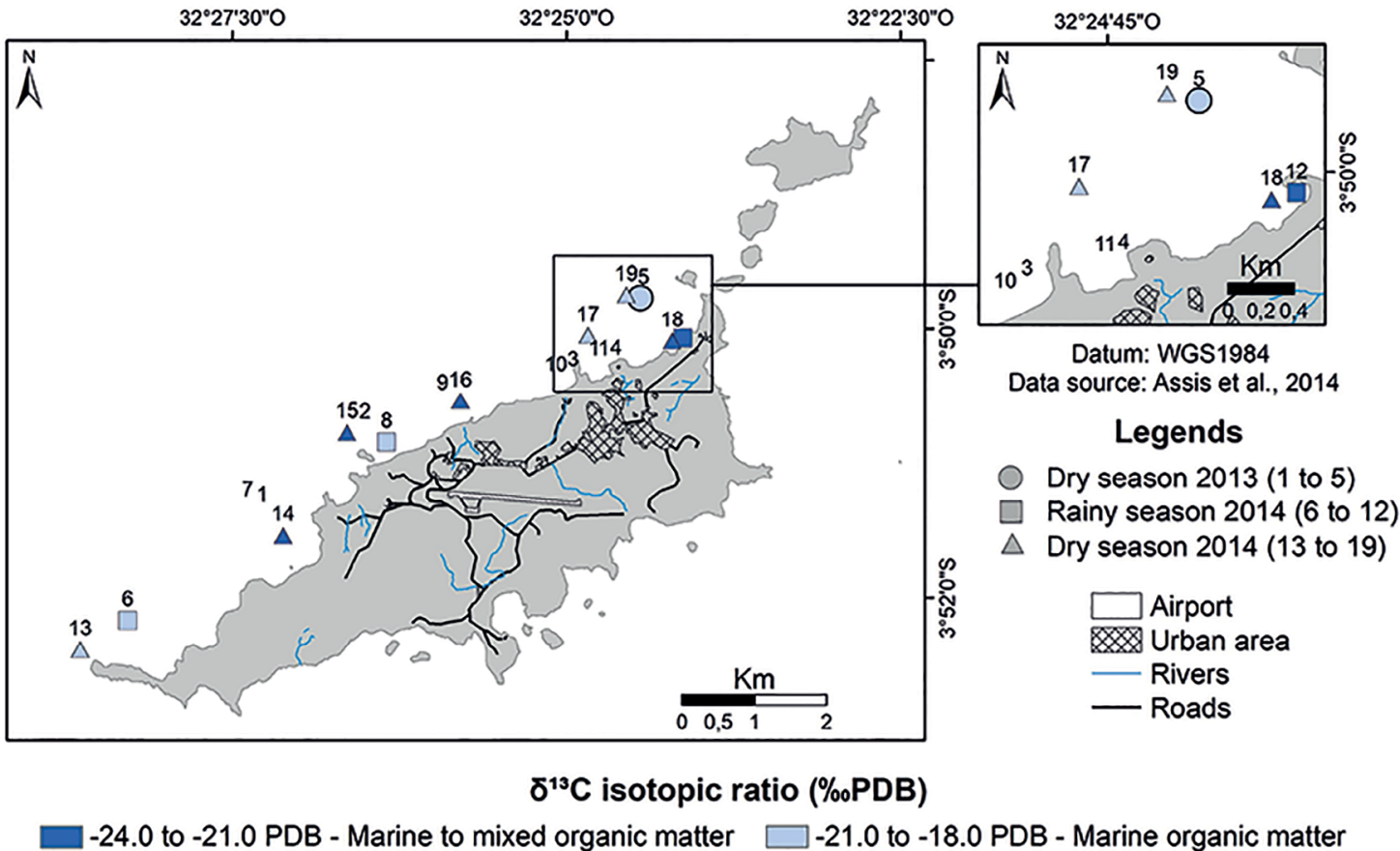

Figure 12. The $\mathrm{d}^{13} \mathrm{C}$ isotopic ratio (in \% $\mathrm{PDB}$ ) at the sediment sampling stations. 
The $\mathrm{C} / \mathrm{N}$ ratio classified the material as coming from continental sources. On the other hand, on the Sueste beach and in the bay the $\mathrm{C} / \mathrm{N}$ values were lower (in general $<12$ ), showing the material to be of marine origin (Barcellos et al., 2011). This pattern could be directly related to low nitrogen values due to faster remineralization than that of carbon, providing a high $\mathrm{C} / \mathrm{N}$ ratio, as observed by Bader (1955) and Corredor et al. (1999). In fact, Assunção et al. (2016) observed that the variation of nutrient concentrations in the FN shelf water column was quite low, near to the minimum detection level, and in many cases below this value, especially in relation to ammonia $\left(\mathrm{NH}_{3}\right)$ concentrations. According to the same authors and corroborating Bader's (1955) statement, this is one of the first products of organic matter mineralization, which is quickly oxidized to the more stable form, nitrate $\left(\mathrm{NO}_{3}\right)$, also found in low concentrations - higher, however, than those of ammonium.

Regarding the C/P ratio (Figure 13), 47\% of the results were below 7, which is the value based on the literature to indicate the processes arising from bacterial metabolism. The remaining 53\% are classified as bacterial activities origin, according to Gächter and Meyer (1993). These values are lower than those expected for classification as organic matter of marine origin (106-300) (Ruttenberg and Goñi, 1997), so it is inferred that this behavior results from the comparatively high phosphorus content in the samples. As previously stated, the volcanic origin of the island would give rise to the presence of material with naturally high levels of phosphorus derived from the composition of the rocks (Rocha et al., 2005). However, the possible local water column enrichment by nutrients due to the upwelling induced by the effect of the island's topography (Teixeira et al., 2003) should also be borne in mind. Added to the guano/phosphorus sources mainly on the protected scarps of the archipelago's secondary islands (Rata, Rasa, do Meio and Sela Gineta islands), that accommodate the nests of innumerable species of sea-birds. The data given by Assunção et al. (2016) could reflect these possible sources, a relative $\mathrm{PO}_{4}^{3-}$ enrichment being observed in the water column of the Fernando de Noronha shelf, samples of which were collected simultaneously with the bottom sediments that generated the data addressed in this article.

\section{STATISTICAL ANALYSIS}

The parameters employed for Principal Component Analysis (PCA) (Figure 14) and clusters (Figure 15) were: $\mathrm{CaCO}_{3}$ content (\%), TOM content (\%), gravel (\%), sand (\%), mud (\%), organic C (\%), organic P $(\mu \mathrm{mol} / \mathrm{g}), \mathrm{C} / \mathrm{P}$ and $\delta^{13} \mathrm{C}$ ratios (\% $\%$ PB), for all the samples collected. In the PCA analysis the two main eigenvectors together held $60.8 \%$ of the total information of the variants, of which the PC1 component had $35.7 \%$ and PC2 complemented with $25.1 \%$. Table 2 describes the main components calculated using the PCA.

PCA and cluster analysis classified the samples into two groups and two isolated samples. The first group (Facies 1) comprised $10.5 \%$ of the samples, classified by significant gravel and mud content (Sts 6 and 17). The second group (Facies 2) comprises $78.9 \%$ of the samples, classified by the predominance of sand. The isolated sample 1 has a higher gravel content (St. 1) and the isolated sample 2 (St.19) has a high mud content.

Table 3 characterizes the sedimentary facies defined by means of cluster analysis and also described in figure 16 .

The statistical analysis was essential to corroborate the absence of a seasonal variation, since the groups formed resemble each other by sedimentary and geochemical composition, as also the isolated samples resemble the other groups by their geochemical composition. Assunção et al. (2016) also observed an absence of seasonal variations in nutrient concentrations in the water column in the same set of sampling stations.

Despite the homogeneity due to the calcareous nature of the shelf sediments, $88.3 \%$ of $\mathrm{CaCO}_{3}$ in average, it is evident that there is a spatial variation of the sedimentary characteristics, as proposed by Manso et al. (2011) for the adjacent beaches, where the SW part of the shelf is dominated by poorly sorted gravelly coarse sands. In its central and NE areas, however, FN's northern shelf is composed essentially of sands, with a prevalence of wellsorted fine sands. In the case of geochemistry results, the sediments generally have a low organic matter content (TOM $<2.87 \%$, TOC $<4.29 \%$, TP $<0.44 \mu \mathrm{mol} / \mathrm{g}$ ) and are mainly of marine origin $\left(\delta^{13} \mathrm{C}>-24.43 \% \mathrm{PDB}\right)$, typical of oligotrophic waters depleted in nutrient concentrations, as observed by Assunção et al. (2016).

Higher contents of organic matter (TOM, TOC, TN and OP) were also observed and found in specific places that permit an association with human activities and natural processes. The Boldró beach (St 8) and Cachorro beach (St 14) samples exhibit medium to high values of TOM, TOC and TP, probably associated with the sewage discharge from local Station of Wastewaters Treatment (SWT) to both areas. In fact, the value of $\delta^{13} \mathrm{C}$ for $\mathrm{St}$ $14(-24.4 \%$ PDB $)$ indicates a mixed origin of SOM and could be associated with the mix of marine algae ( -18 to -24\% PDB) (Stein, 1991) and organic matter of sewage 


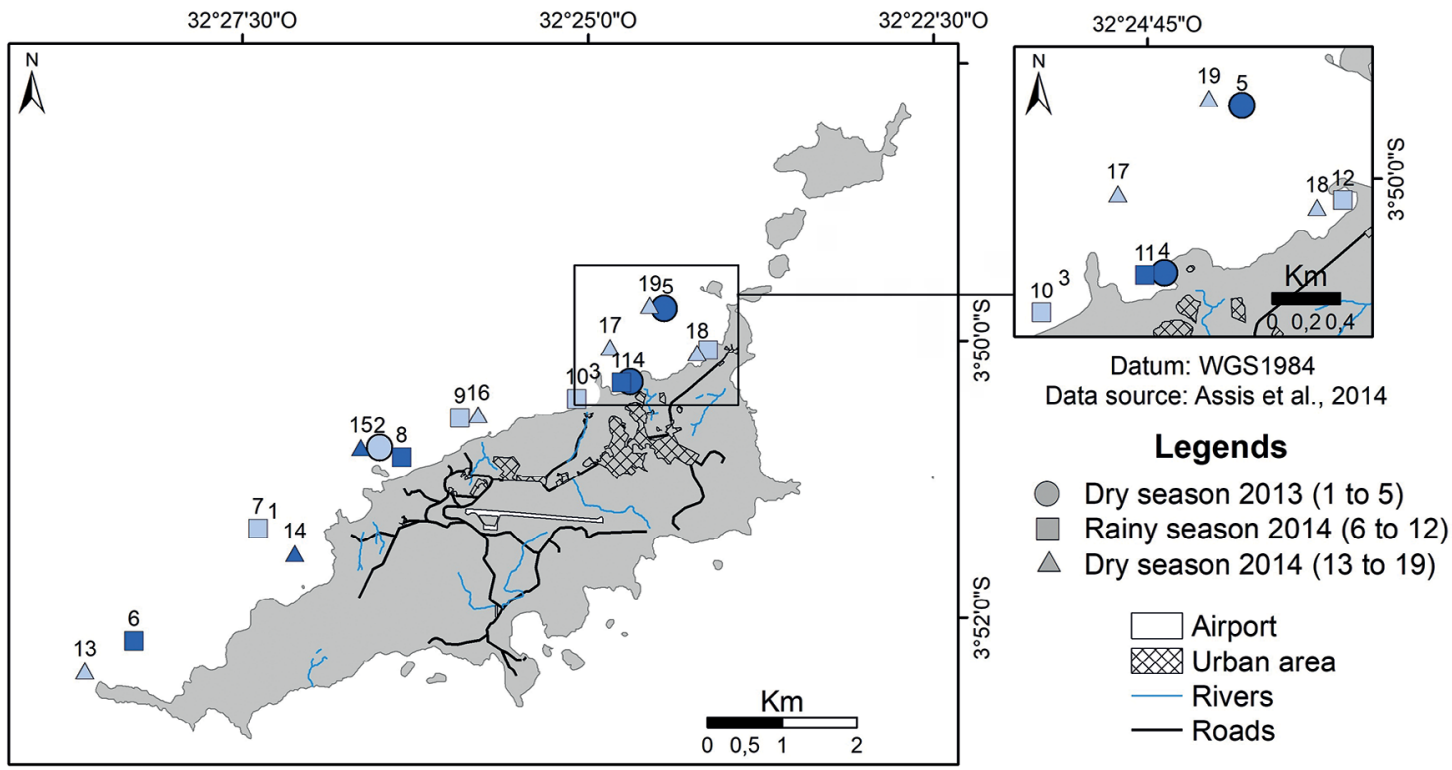

\section{C/P Ratio}

\section{$<7.0 \square 7.0$ to 80.0 - Bacterian activity $\square 80.0$ to 300 - Marine origin}

Figure 13. The elemental C/P ratios of FN's northern shelf sediments.

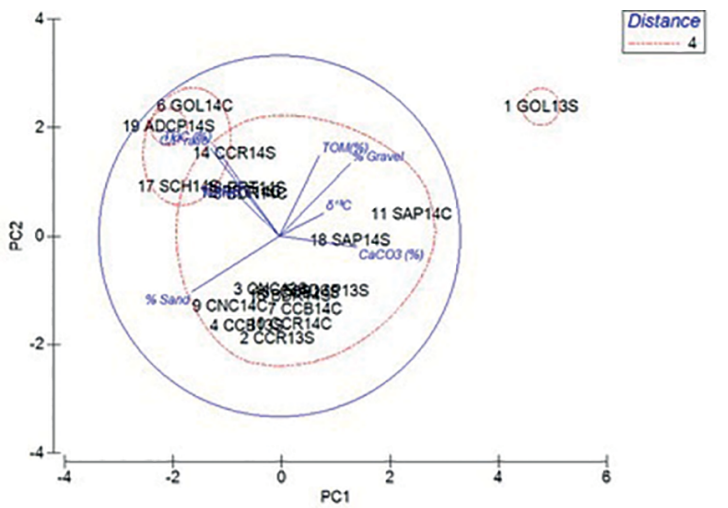

Figure 14. The principal component analysis (PCA) of FN's northern shelf sediments.

origin (-26.7\% $\mathrm{PDB})$ (Thornton and Mcmanus, 1994; Andrews et al., 1998). The port and ADCP mooring sampling stations (Sts 5, 12, 13 and 19) presented medium values of TOC and TP that could also be related to the harbor activities, and a slightly higher mud content for St $19(>4.0 \%)$. In the case of the Golfinhos Bay samples (Sts 1,6 and 17), the comparatively higher contents of TOM, TOC, especially of TN and TP, seem to be directly related to the dolphins frequenting the area.
Overall, this article presents new spatial and temporal sedimentary data, that joined to the previous studies of phosphorus in soils (Rocha et al., 2005), adjacent beaches (Manso et al., 2011), the Sueste Bay sedimentary system (Barcellos et al. 2011, 2016a) brings important contributions to geological knowledge of Fernando de Noronha costal and shelf environments.

In summary: (1) the medium contents of phosphorus species in the shelf sediments could be directly linked to volcanic rocks phosphatic sources in the island and also to local primary productivity; (2) the textural similarity among the adjacent beaches and shelf is remarkable; and (3) the elemental and isotopic OM in bottom sediments indicate signals of the anthropic land-ocean fluxes, when compared to the pristine Sueste system surrounded by natural OM sources.

\section{CONCLUSIONS}

Regardless of the seasonal period, the adjacent island shelf on the northern coast of the Fernando de Noronha archipelago has a calcareous sandy sedimentary cover, with a predominance of fine sand and well sorted grains. The material consists of bioclastic sediments, with low organic matter 


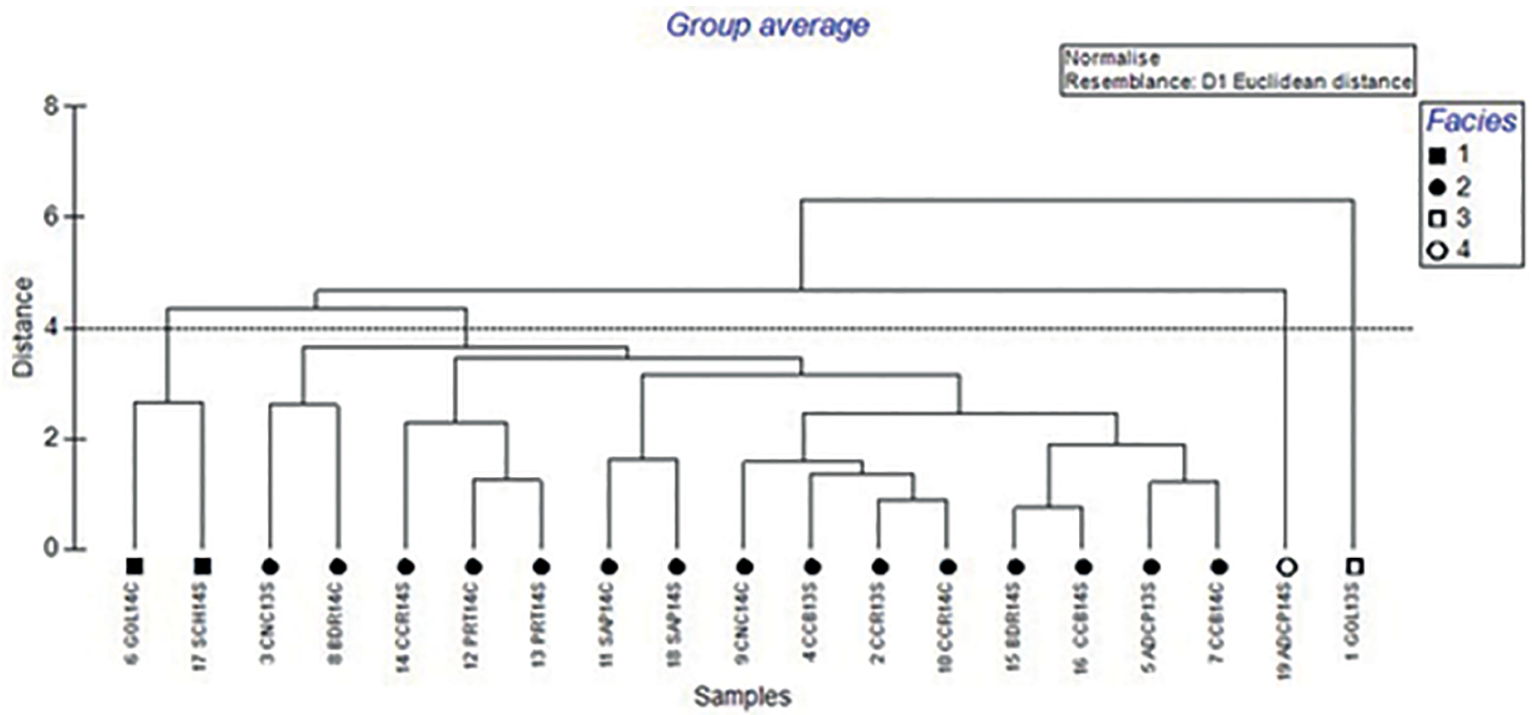

Figure 15. The cluster analysis of FN's northern shelf sediments.

Table 2. Principal components calculated by PCA.

\begin{tabular}{lcc}
\hline Variable & PC1 & PC2 \\
\hline $\mathrm{CaCO}_{3}$ contents (\%) & 0.407 & -0.091 \\
Total Organic Matter (\%) & 0.278 & 0.413 \\
\% Gravel & 0.524 & 0.231 \\
\% Sand & -0.520 & -0.248 \\
\% Fine & -0.136 & 0.303 \\
Total Organic Carbon (\%) & -0.258 & 0.565 \\
$\mathrm{C} / \mathrm{P}$ ratio & -0.284 & 0.540 \\
$\delta^{13} \mathrm{C}(\% \mathrm{PDB})$ & 0.215 & 0.061 \\
\hline
\end{tabular}

content of marine origin. However, the SW part of this shelf is dominated by poorly sorted gravelly coarse sands.

The sedimentary distribution patterns observed reflect the bottom morphology, wave action, currents and the location of biogenic and lithoclastic sediment sources. Since the gravel distribution on the shelf and beaches is similar and seems to be adjusted, as well as for the biogenic sands present in both sites on the central and eastern areas.

The present data made it possible to infer that there is no seasonal variation in sediment distribution. There are some stations that show a relative enrichment in organic matter, and this might be related to human actions of impact, in particular, sewage outflow from SWT (at the Cachorro and Boldró Beaches) and port activities (at the Harbor and ADCP mooring sampling stations).
Finally, the relative enrichment of total phosphorus in all the samples collected as also of total nitrogen, mainly in Golfinhos bay, seem, respectively, to be associated with natural biotic (dolphins, guano) and abiotic (upwelling, rock sources) processes in the local insular shelf's geosystem.

\section{ACKNOWLEDGMENTS}

The authors' thanks are due to FACEPE/FAPESP for their financial support given for the project (proc. FACEPE $n^{\circ}$ : 0074-1.08/11 and FAPESP 2011/50582$0)$ "Carbon transport in a coastal region of Pernambuco State - CARECOS" and to CAPES for the support from the project (proc. $\mathrm{n}^{\mathrm{o}}$ : 23038.001423/2014-29) "Studies on dissolved inorganic carbon in coastal areas of $\mathrm{N}$ and $\mathrm{NE}$ regions of Brazil and its relation with the marine acidification processes - DICAM". And to the "Spinnning Dolphin Project" and José Martins da Silva (ICMBio) for the logistical support and the sampling authorization in Baía do Golfinhos and Mar de Dentro. The authors also wish to express their thanks to Luciana Santos, Diego Xavier, Eduardo Martins, Felipe Gaspar, Josiane Paulo and Bruno Varela, members of Labogeo/GSGMar, Loquim and Organomar of the Federal University of Pernambuco (UFPE), Brazil. 
Table 3. Characteristics of the recognized sedimentary classes by cluster analysis (Cluster).

\begin{tabular}{lcccccccc}
\hline Facies & $\mathrm{CaCO}_{3}(\%)$ & $\begin{array}{c}\text { Total Or- } \\
\text { ganic } \\
\text { Matter (\%) }\end{array}$ & $\begin{array}{c}\text { Total Or- } \\
\text { ganic } \\
\text { Carbon (\%) }\end{array}$ & $\mathrm{C} / \mathrm{P}$ & $\delta^{13} \mathrm{C}\left(\%{ }_{0} \mathrm{PDB}\right)$ & \% Gravel & \% Sand & \% Mud \\
\hline Facies 1 & 75.85 & 1.57 & 1.87 & 10.24 & -21.62 & 8.46 & 91.42 & 0.12 \\
Facies 2 & 89.26 & 1.47 & 1.24 & 8.64 & -22.75 & 2.57 & 97.12 & 0.30 \\
Isolated 1 & 98.10 & 2.47 & - & - & - & 89.29 & 10.57 & 0.14 \\
Isolated 2 & 89.20 & 1.67 & 2.94 & 23.05 & -23.31 & 0.00 & 95.82 & 4.18 \\
\hline
\end{tabular}

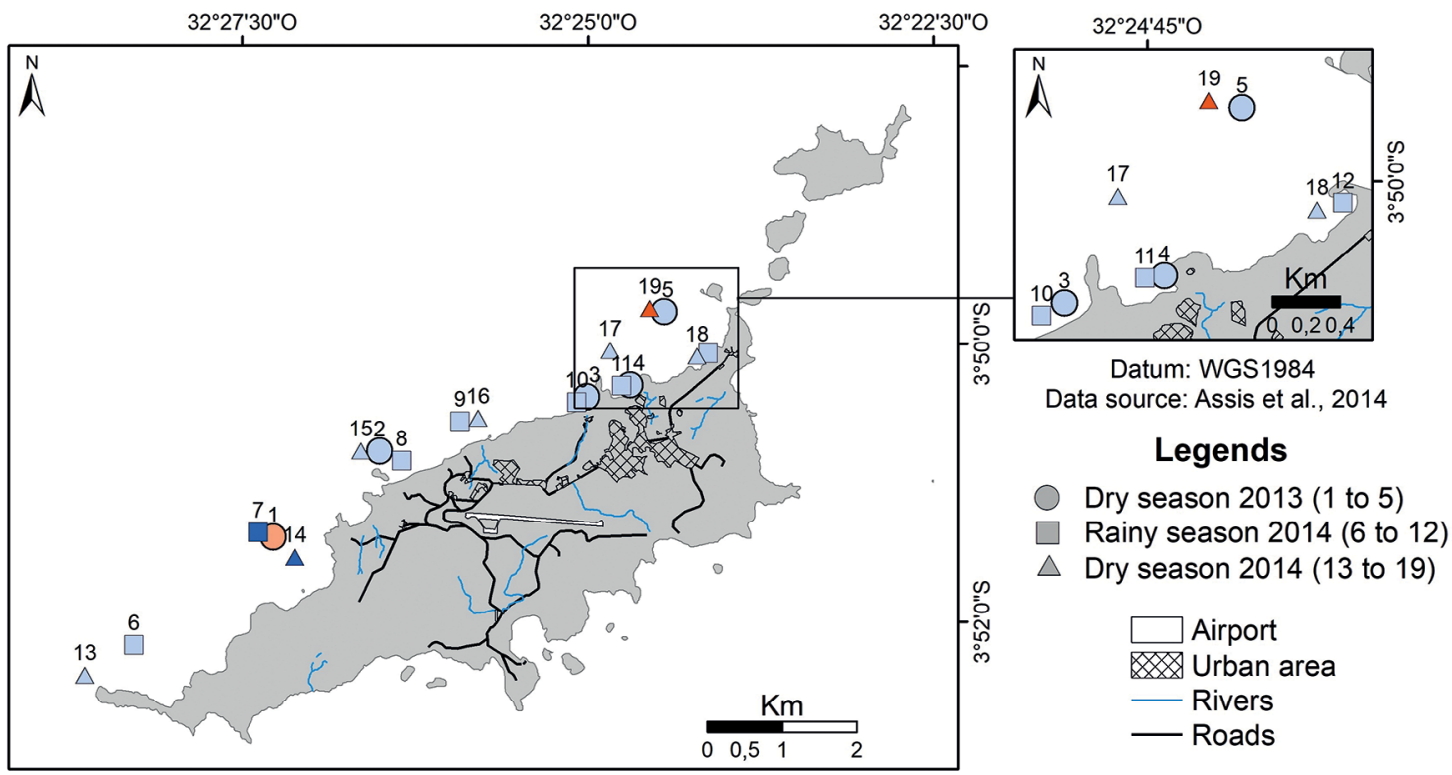

Facies

Facies $1 \quad \square$ Facies $2 \square$ Isolated $1 \square$ Isolated 2

Figure 16. Sedimentary facies distribution for FN's northern shelf based on Cluster Analysis.

\section{REFERENCES}

ALMEIDA, F. F. M. 1955. Geologia e petrologia do arquipélago de Fernando de Noronha. Departamento Nacional de Produção Mineral-DNPM. Rio de Janeiro, Serviço Gráfico do Instituto Brasileiro de Geografia e Estatística.

ALMEIDA, F. F. M. 2000. Arquipélago de Fernando de Noronha. In: SCHOBBENHAUS, C., CAMPOS, D. A., QUEIROZ, E. T., WINGE, M. \& BERBERT-BORN, M. (eds.) Sitios geológicos e paleontológicos do Brasil. Brasília: Comissão Brasileira de Sítios Geológicos e Paleobiológicos-SIGEP/Departamento Nacional de Produção Mineral-DNPM/Serviço Geológico do Brasil-CPRM.

ALMEIDA, F. F. M. D. 2006. Ilhas oceânicas brasileiras e suas relações com a tectônica atlântica. Terrae Didática, 2, 3-18.

ALVE, E. 1995. Benthic foraminifera responses to estuarine pollution: a review. Journal of Foraminiferal Research, 25, 190-203.
ANDREWS, J. E., GREENAWAY, A. M. \& DENNIS, P. F. 1998. Combined Carbon isotope and $\mathrm{C} / \mathrm{N}$ ratios as indicators of source and fate of organic matter in a poorly flushed, tropical estuary: Hunts bay, Kingston Harbour, Jamaica. Estuarine Coastal and Shelf Science, 46, 743-756.

ASSIS, H. M. B.; GOMES, R. B.; SALVIANO, K. S.; PEREIRA, L. B. F.; OLIVEIRA, P. R. A. rigeo.cprm.gov.br/jspui/bitstream/doc/17497/3/mdt.pdf

ASSUNÇÃO, R. V., SILVA, A. C., MARTINS, J. \& FLORES-MONTES, M. J. 2016. Spatial-Temporal Variability of the thermohaline properties in the coastal region of the Fernando de Noronha Arquipélago, Brazil. Journal of Coastal Research, 75, 512-516.

BARCELLOS, R. L., BERBEL, G. B. B., BRAGA, E. S. \& FURTADO, V. V. 2005. Distribuição e características do fósforo sedimentar no sistema estuarino-lagunar de Cananéia-Iguape, Estado de São Paulo, Brasil. Geochimica Brasiliensis, 19, 22-36. 
BARCELLOS, R. L., COELHO-JÚNIOR, C., LINS, S. R., SILVA, M. S., CAMARGO, P. B. \& TRAVASSOS, P. E. 2011. Island beaches morphological and sedimentary short term variations the case of SE Fernando de Noronha Island, South Atlantic, Brazil. Revista da Gestão Costeira Integrada, 11, 471-478.

BARCELLOS, R. L., LINS, S. R. \& COELHO-JÚNIOR, C. 2016a. Sedimentação e Geoquímica Costeira em uma Ilha Oceânica Brasileira, Saarbrücken: NEA.

BARCELlOS, R. L., MONTES, M. J. F., ALVES, T. M. F. \& CAMARGO, P. B. 2016b. Modern sedimentary processes and seasonal variations of organic matter in an urban tropical estuary, Jaboatão River (PE), Brazil. Journal of Coastal Research, 75, 38-42.

BADER, R. G. 1955. Carbon and nitrogen relations in surface and subsurface marine sediments. Geochimica et Cosmochimica Acta, 7, 205-211.

BARROS, L. C., VALENÇA, L. M. M., MANSO, V. D. A. V., MADRUGA FILHO, J. D., \& OLIVEIRA, J. A. R. 2007. Textura, composição e arredondamento dos sedimentos da plataforma continental interna adjacente às desembocaduras sul do canal de Santa Cruz e do Rio Timbó, norte do Estado de Pernambuco. Estudos Geológicos, 17, 58-70.

BORDOVSKIY, O. K. 1965. Accumulation of organic matter in bottom sediments. Marine Geology, 3,33-82.

BROWN, J., COOLING, A., PARK, D., PHILlIPS, J., ROTHERY, D. \& WRIGHT, J. 1989. Ocean Circulation, Oxford, The Open University and Pergamon Press.

BURRUS, D., THOMAS, R. L., DOMINIK, J. \& VERNET, J. P. 1990. Seasonal delivery of the particulate forms of phosphorus to Lake Geneva from the upper Rhone river. Aquatic Sciences, 52, 221-235.

CATACOSINOS, P. A. 1965. Tables for the determination of sphericity and shape of rock particles. Journal of Sedimentary Research, 35, 354-365.

CARVER, R. E. 1971. Procedures in Sedimentary Petrology, New York, Wiley Interscience.

CHESTER, R. \& RILEY, J. P. 1978. Chemical Oceanography, London, Academic Press Inc. Ltd.

CLARK, J. R. 1977. Coastal Ecosystem Management, New York, John Wiley \& Sons.

CPRM (Serviço Geológico do Brasil). 2014. [cited 2017 Jun 09]. Available from: http://www.cprm.gov.br/publique/Noticias $/ 3172 . h t m$

CORDANI, U. G. 1970. Idade do vulcanismo no oceano Atlântico Sul. Boletim IGA, 1, 9-75.

CORREDOR, J. E., HOWARTH, R. W., TWILLEY, R. R., \& MORELL, J. M. 1999. Nitrogen cycling and anthropogenic impact in the tropical interamerican seas. Biogeochemistry, $46,163-178$.

DHN (Diretoria de Hidrografia e Navegação). 2005. Carta Náutica de Fernando de Noronha. $\mathrm{N}^{\mathrm{o}} 52$. Rio de Janeiro, Ministério da Marinha.

DIAS, J. C. \& LIMA, W. N. 2004. Comparação de Métodos para a Determinação de Matéria Orgânica em Amostras Ambientais. Revista Cientifica da UFPA, 4, 1-15.

DIJKSTRA, N., JUNTTILA, J., SKIRBEKK, K., CARROLL, J., HUSUM, K. \& HALD, M. 2017. Benthic foraminifera as bio-indicators of chemical and physical stressors in Hammerfest harbor (Northern Norway). Marine Pollution Bulletin, 114, 384-396.
DIMIZA, M. D., TRIANTAPHYLLOU, M. V., KOUKOUSIOURA, O., HALLOCK, P., SIMBOURA, N., KARAGEORGIS, A. P. \& PAPATHANASIOU, E. 2016a. The Foram Stress Index: A new tool for environmental assessment of soft-bottom environments using benthic Foraminifera. A case study from the Saronikos Gulf, Greece, Eastern Mediterranean. Ecological Indicators, 60, 611-621.

DIMIZA, M. D., KOUKOUSIOURA, O., TRIANTAPHYLLOU, M. V. \& DERMITZAKIS, M. D. 2016b. Live and dead benthic foraminiferal assemblages from coastal environments of the Aegean Sea (Greece): Distribution and diversity. Revue de Micropaléontologie, 59, 19-32.

EDWARDS, A. \& LUBBOCK, R. 1983. Marine zoogeography of St Paul's Rocks. Journal of Biogeography, 10, 65-72.

ENNIS, R. S., BRANDT, M. E., GRIMES, K. R. W. \& SMITH, T. B. 2016. Coral reef health response to chronic and acute changes in water quality in St. Thomas, United States Virgin Islands. Marine Pollution Bulletin, 111, 418-427.

ESTON, V. R. D., MIGOTTO, A. E., OLIVEIRA FILHO, E. C. D., RODRIGUES, S. D. A. \& FREITAS, J. C. D. 1986. Vertical distribution of benthic marine organisms on rocky coasts of the Fernando de Noronha Archipelago (Brazil). Boletim do Instituto Oceanográfico, 34, 37-53.

EVERSOLE, D. \& FLETCHER, C. H. 2003. Longshore sediment transport rates on a reef-fronted beach: field data and empirical models Kaanapali Beach, Hawaii. Journal of Coast Research, 19, 649-663.

FOLK, R. L. \& WARD, W. C. (1957). Brazos River Bar: Study of the Significance of Grain Size Parameters. Journal of Sedimentary Petrology, 27, 3-27.

FRANKOWSKI, L., BOLAŁEK, J. \& SZOSTEK, A. 2002. Phosphorus in bottom sediments of pomeranian bay (Southern Baltic-Poland). Estuarine Coastal and Shelf Science, 54, 1027-1038.

FRONTALINI, F. \& COCCIONI, R. 2011. Benthic foraminifera as bioindicators of pollution: a review of Italian research over the last three decades. Revue de Micropaleontologie, 54, 115-127.

GÄCHTER, R. AND J.S. MEYER. 1993. The role of microorganisms in the mobilization and fixation of phosphorus in sediments. Hydrobiologia 253: 103-121.

GARRISON, T. 2016. Fundamentos de Oceanografia, São Paulo, Cengage Learning.

GENZ, A. S., FLETCHER, C. H., DUNN, R. A., FRAZER, L. N. \& ROONEY, J. J. 2007. The predictive accuracy of shoreline change rate methods and alongshore beach variation on Maui, Hawaii. Journal of Coastal Research, 23, 87-105.

GRASSHOFF, K. EHRHARDT, M. \& KREMELING, K. 1983. Methods of seawater analysis, Weinhein, Verlag Chemie.

HEDGES, J. I. \& STERN, J. H. 1984. Carbon and nitrogen determinations of carbonate-containing solids. Limnology and Oceanography, 29, 657-663.

HÖFLICH, O. 1984. Climate of the South Atlantic ocean. In: VAN LOON, H. (ed.) World survey of climatology, Oxford: Elsevier.

HUBERT, J. F. 1971. Analisys of Heavy-mineral Assemblages. In: CARVER, R. E. (ed.) Procedures in Sedimentary Petrology, New York: Wiley-Interscience.

IBGE (Instituto Brasileiro de Geografia e Estatística). 2010. Censo 2010. [cited 2015 Jan]. Available from: http://www. censo2010. ibge. gov. br/ 
JOHNSON, H. D. \& BALDWIN, C. T. 1996. Shallow clastic seas. In: READING, W. (ed.) Sedimentary environments: processes, facies and stratigraphy, Oxford: Blackwell Science.

KENCH, P. S. 1997. Contemporary sedimentation in the Cocos (Keeling) Islands, Indian Ocean:interpretation using settling velocity analysis. Sedimentary Geology, 114, 109-130.

KING, C. A. M. 1972. Beaches and coasts, London, Edward Arnold.

LAMB, A. L., GRAHAM, P. W. \& LENG, M. J. 2006. A review of coastal palaeoclimate and relative sea-level reconstructions using $\delta^{13} \mathrm{C}$ and $\mathrm{C} / \mathrm{N}$ ratios in organic matter. Earth-Science Reviews, 75, 29-57.

LARSSONEUR, C., BOUYSSE, P. \& AUFRET, J. P. 1982. The surpeficial sediments of the English Channel and its western approaches. Sedimentology, 29, 851-864.

MAHIQUES, M. M. 1987. Considerações sobre os Sedimentos de Superficie de Fundo da Baía da Ilha Grande, Estado do Rio de Janeiro [Dissertation]. Instituto Oceanográfico da Universidade de São Paulo.

MAHIQUES, M. M., TESSLER M. G. \& FURTADO V. V. 1998. Characterization of Energy Gradient in Enclosed Bays of Ubatuba Region, South-Eastern Brazil. Estuarine Coastal and Shelf Science, 47, 431-446.

MANSO, V. A. V., MENOR, E. A., VALENÇA, L. M. M., NEUMANN, V. H. M. L., PEREIRA, N. S., JUNIOR, C. F. A. S. \& SILVA, E. R. M. 2011. Morfodinâmica de praias setentrionais da Ilha de Fernando de Noronha. Revista da Gestão Costeira Integrada, 11, 327-339.

MARTINS, V. A., FRONTALINI, F., TRAMONTE, K. M., FIGUEIRA, R. C. L., MIRANDA, P., SEQUEIRA, C., FERNÁNDEZ-FERNÁNDEZ, S., DIAS, J. A., YAMASHITA, C., LAUT, L. M., SOBRINHO, F., RODRIGUES, M. A., BERNARDES, C., NAGAI, R., SOUSA, S. S. M., MAHIQUES, M., RUBIO, B., BERNABEU, A., REY, D. \& ROCHA, F. 2013. Assessment of the health quality of Ria de Aveiro (Portugal): heavy metals and benthic foraminifera. Marine Pollution Bulletin, 70, 18-33.

MARTINS, V. A., SILVA, F., LAZARO, L. M. L., FRONTALINI, F., CLEMENTE, I. M., MIRANDA, P., FIGUEIRA, R. SOUSA, S. H. M. \& DIAS, J. M. A. 2015a. Response of benthic foraminifera to organic matter quantity and quality and bioavailable concentrations of metals in Aveiro Lagoon (Portugal). PLoS One, 10, e0118077.

MARTINS, M. V. A., ZAABOUB, N., ALEYA, L., FRONTALINI, F., PEREIRA, E., MIRANDA, P., MANE, M., ROCHA, F., LAUT, L. \& EL BOUR, M. 2015b. Environmental quality assessment of Bizerte Lagoon (Tunisia) using living foraminifera assemblages and a multiproxy approach. PLoS One, 10, e0137250.

MARTINS, M. V. A., PINTO, A. F. S., FRONTALINI, F., DA FONSECA, M. C. M., TERROSO, D. L., LAUT, L. L. M. \& ROCHA, F. 2016. Can benthic foraminifera be used as bio-indicators of pollution in areas with a wide range of physicochemical variability? Estuarine Coastal and Shelf Science, 182, 211-225.

MCMANUS, D. A. 1975. Modern versus relict sediment on the continental shelf. Geological Society of America Bulletin, 86, $1154-1160$

MENDES, L. D. F. 2006. História natural dos amborés e peixes-macaco (Actinopterygii, Blennioidei, Gobioidei) do Parque Nacional Marinho do Arquipélago de Fernando de Noronha, sob um enfoque comportamental. Revista Brasileira de Zoologia, 23, 817-823.
MEYERS, P. A. 1997. Organic Geochemical Proxies of Paleoceanography, Paleolminologic and Paleoclimatic Processes. Organic Geochemistry, 27, 213-250.

MONTALVO, J. F., PERIGÓ ARNAUD, E., MARTÍNEZ, M., GARCÍA, I., ESPONDA, S. C., CESAR, M. E., GARCÍA, R., LÓPEZ, D., GARCÍA, N. \& BLANCO, M. 2010. Compuestos de nitrógeno y fósforo en las aguas superficiales de tres zonas de la plataforma marina cubana. Serie Oceanológica, 7, 27-36.

MÜLLER, G. 1967. Methods in sedimentary petrography (Part I), New York, Hafner Publishing.

MURRAY, J. 2006. Ecology and Applications of Benthic Foraminifera, New York, Cambridge University Press.

NASCIMENTO, C. W. A. 2002. Fertilidade dos solos da Ilha de Fernando de Noronha. In: Reunião Brasileira de Fertilidade do Solo e Nutrição de Plantas-FERTBIO. Rio de Janeiro: UFRRJ.

NORCROSS, Z. M., FLETCHER, C. H. \& MERRIFIELD, M. 2002. Annual and interannual changes on a reef-fringed pocket beach: Kailua Bay, Hawaii. Marine Geology, 190, 553580 .

OGRINC, N., FONTOLAN, G., FAGANELI, J. \& COVELLI, S. 2005. Carbon and nitrogen isotope compositions of organic matter in coastal marine sediments (the Gulf of Trieste, $\mathrm{N}$ Adriatic Sea): indicators of sources and preservation. Marine Chemistry, 95, 163-181.

OLIVEIRA, T. S., BARCELLOS, R. L., SCHETTINI, C. A. F. \& CAMARGO, P. B. 2014. Processo sedimentar atual e distribuição da matéria orgânica em um complexo estuarino tropical, Recife, PE, Brasil. Revista da Gestão Costeira Integrada, 14, 399-411.

PARDO, L. H., KENDALL, C., PETT-RIDGE, J., \& CHANG, C. C. 2004. Evaluating the source of streamwater nitrate using $\delta^{15} \mathrm{~N}$ and $\delta^{18} \mathrm{O}$ in nitrate in two watersheds in New Hampshire, USA. Hydrological Processes, 18, 2699-2712.

PEREIRA, N. S. MANSO, V. A. V., SILVA, A. M. C. \& SILVA, M. B. 2010. Mapeamento geomorfológico e morfodinâmica do Atol das Rocas, Atlântico Sul. Revista da Gestão Costeira Integrada, 10, 331-345.

PESSENDA, L. C. R., GOUVEIA, S. E. M., LEDRU, M. P., ARAVENA, R., RICARDI-BRANCO, F. S., BENDASSOLLI, J. A., RIBEIRO, A. S., SAIA, S. E. M. G., SIFFEDDINE, A., MENOR, E. A., OLIVEIRA, S. M. B., CORDEIRO, R. C., FREITAS, A. M. M., BOULET, R. \& FILIZOLA, H. F. 2008. Interdisciplinary paleovegetation study in the Fernando de Noronha island (Pernambuco state), NE Brazil. Anais da Academia Brasileira de Ciências, 80, 677-691.

PHILANDER, S. G. 1990. El Niño, La Niña and Southern oscillation. International Geophysics Series, New York, Academic Press.

PILKEY, O. H., MORTON, R. W. \& LUTERNAUER, J. 1967. The carbonate fraction of beach and dune sands. Sedimento$\log y, 8,311-327$.

PONZI, V. R. A. 2004. Sedimentação marinha. In: BAPTISTA NETO, J. A., PONZI, V. R. A. \& SICHEL, S. E. (eds.) Introdução à Geologia Marinha. Rio de Janeiro: Interciência.

REIDHAAR, P. E., LANE, C. S., BENITEZ-NELSON, C. R. \& GAMBLE, D. W. 2016. Spatial and Temporal Variations in Pyrodinium bahamense Cyst Concentrations in the Sediments of Bioluminescent Mangrove Lagoon, St. Croix, USVI. Estuaries and Coasts, 39, 682-694. 
ROCHA, A. T. D., DUDA, G. P., NASCIMENTO, C. W. \& RIBEIRO, M. R. 2005. Phosphorus fractionation and evaluation of available-P extractors in soils of Fernando de Noronha Island. Revista Brasileira de Engenharia Agrícola e Ambiental, 9, 178-184.

ROMANKEVICH, E. A. 1984. Geochemistry of Organic Matter in the Ocean, New York, Springer-Verlag.

RUTTENBERG, K. C. \& GOÑI, M. A. 1997. Phosphorus distribution, (C:N:P) ratios, and delta super(13)C sub()oc in Arctic, temperate, and tropical coastal sediments: Tools for characterizing bulk sedimentary organic matter. Marine Geology, $139,123-145$.

SAHU, B. K. 1964. Depositional mechanisms from the size analysis of clastic sediments. Journal of Sedimentary Research, 34,73-83.

SANTOS, C. A. R. R. D. 2002. Eolianitos de Fernando de Noronha: processos deposicionais e pós-deposicionais [Dissertation]. Universidade Federal de Pernambuco.

SHEPARD, F. P. 1954. Nomenclature based on sand-silt-clay ratios. Journal of Sedimentary Petrology, 24, 151-158.

SHEPARD, F. P. \& MOORE, D. G. 1954. Sedimentary environments differentiated by coarse-fraction studies. AAPG Bulletin, 38, 1792-1802.

SILVA, JR, J. M., SILVA, F. J. D. L., SAZIMA, C. \& SAZIMA, I. 2007. Trophic relationships of the spinner dolphin at Fernando de Noronha Archipelago, SW Atlantic. Scientia Marina, 71,505-511.

SMITH, D. A. \& CHEUNG, K. F. 2002. Empirical relationships for grain size parameters of calcareous sand on Oahu, Hawaii. Journal of Coastal Research, 18, 82-93.

STEIN, R. 1991. Accumulation of Organic Carbon in Marine Sediments. Results from the Deep Sea Drilling Project/ Ocean Drilling Program. In: BHATTACHARJI, S., FRIEDMAN, G. M., NEUGEBAUER, H. J. \& SEILACHER, A. (eds.) Lecture Notes in Earth Sciences. Berlin: Springer.

STRAMMA, L. \& ENGLAND, M. 1999. On the water masses and mean circulation of the South Atlantic Ocean. Journal of Geophysical Research, 104, 20863-20883.

STRONGE, W. B. 1994. Beaches, tourism, and economic development. Shore and Beach, 6-8.

SUGUIO, K. 1973. Introdução Sedimentologia, São Paulo, Edgard Blücher.

TEIXEIRA, W., CORDANI, U. G., MENOR, E. A., TEIXEIRA, M. G. \& LINSKER, R. 2003. Arquipélago de Fernando de Noronha. O paraíso do Vulcão. Tempos do Brasil, São Paulo, Terra Virgem Editora.
THOMSON, R. E. 1981. Oceanography of the British Columbia coast. No. 56. Ottawa, Department of Fisheries and Oceans.

THORNTON, S. F. \& MCMANUS, J. 1994. Application of organic carbon and nitrogen stable isotope and $\mathrm{C} / \mathrm{N}$ ratio as source indicators of organic matter provenance in esturine systems: evidence from the Tay Estuary, Scotland. Estuarine Coastal and Shelf Science, 38, 219-233.

THURMAN, H. V. 1994. Introductory Oceanography, New York, Macmillan Publ. Co.

TRAVASSOS, R. K., MONTES, M. J. F., DA COSTA, B. V. M. \& DA SILVA JÚNIOR, J. M. 2016. The Influence of Urban Effluents on the Elemental C/N Ratio in a Tropical Coastal Area of Northeastern Brazil. Journal of Coastal Research, 75, 168-172.

TYSON, R. V. 1995. Sedimentary Organic Matter. London, Chapman \& Hall.

VALENÇA, L. M. M., NEUMANN, V. H., MENOR, E. A. \& SANTOS, C. E. R. R. 2005. Eolianitos de Fernando de Noronha: Uma análise integrada de estudos petrográficos e geoquímicos. In: Anais do $10^{\circ}$ Congresso da Associação Brasileira de Estudos do Quaternário-ABEQUA. 37-39.

VINOGRADOV, M. 1981. Ecosystems of equatorial upwelling. In: Longhurst. A. R. (ed.) Analysis of Marine Ecosystems. New York: Academic Press.

WILDNER, W. \& FERREIRA, R. V. 2011. Projeto Geoparques Fernando de Noronha - PE (Proposta). Serviço Geológico Do Brasil - CPRM. [cited 2018 Mar 15]. Available from: http:/www.cprm.gov.br/publique/media/Gestao-territorial/ geoparques/noronha1/index.php?GEOPARQUE $=1$

WILLIAMS, J. D. H., MURPHY, T. P. \& MAYER, T. 1976. Rates of accumulation of phosphorus forms in Lake Erie sediments. Journal of the Fisheries Board of Canada, 33, 430-439.

WILSON, J. L. 2012. Carbonate Facies in Geologic History, New York, Springer Science \& Business Media.

YANKO, V., AHMAD, M. \& KAMINSKI, M. 1998. Morphological deformities of benthic foraminiferal tests in response to pollution by heavy metals: implications for pollution monitoring. Journal of Foraminiferal Research, 28, 177-200.

YAMAMURO, M., KAYANNE, H. \& YAMANO, H. $2003 \delta^{15} \mathrm{~N}$ of seagrass leaves for monitoring anthropogenic nutrient increases in coral reef ecosystems. Marine Pollution Bulletin, $46,452-458$

YAMAMURO, M. \& KAMIYA, H. 2014. Elemental (C, N, P) and isotopic $\left(\delta^{13} \mathrm{C}, \delta^{15} \mathrm{~N}\right)$ signature of primary producers and their contribution to the organic matter in coastal lagoon sediment. Landscape and Ecological Engineering, 10, 65-75. 